OPEN ACCESS

Edited by:

Erin E. Connor,

University of Delaware, United States

Reviewed by:

Renae Charalambous,

The University of

Queensland, Australia

Kai Liu,

City University of Hong Kong,

Hong Kong, SAR China

*Correspondence:

Md. Sohel Rana

ranasoheldvm06@gmail.com

Specialty section

This article was submitted to Animal Physiology and Management,

a section of the journal

Frontiers in Animal Science

Received: 23 April 2021

Accepted: 16 August 2021

Published: 08 September 2021

Citation:

Rana MS and Campbell DLM (2021)

Application of Ultraviolet Light for

Poultry Production: A Review of

Impacts on Behavior, Physiology, and

Production.

Front. Anim. Sci. 2:699262.

doi: 10.3389/fanim.2021.699262

\section{Application of Ultraviolet Light for Poultry Production: A Review of Impacts on Behavior, Physiology, and Production}

\author{
Md. Sohel Rana ${ }^{1,2,3 *}$ and Dana L. M. Campbell ${ }^{1,2}$ \\ ${ }^{1}$ School of Environmental and Rural Science, University of New England, Armidale, NSW, Australia, ${ }^{2}$ Agriculture and Food, \\ Commonwealth Scientific and Industrial Research Organisation (CSIRO), Armidale, NSW, Australia, ${ }^{3}$ Department of Livestock \\ Services, Ministry of Fisheries and Livestock, Dhaka, Bangladesh
}

The application of ultraviolet (UV) light in poultry production is garnering increased interest with the drive toward improved poultry welfare and optimized production. Poultry can see in the UV spectrum (UVA wavelengths: $320-400 \mathrm{~nm}$ ) thus inclusion of these shorter wavelengths may be viewed as more natural but are typically excluded in conventional artificial lights. Furthermore, UVB wavelengths (280-315) have physiological impact through stimulation of vitamin D pathways that can then improve skeletal health. However, better understanding of the effects of UV supplementation must occur before implementation practically. This non-systematic literature review aimed to summarize the impacts of UV supplementation on the behavior, welfare, and production of laying hens, meat chickens (breeders and growers), and other domestic poultry species including directions for future research. The literature demonstrated that UVA light has positive impacts on reducing fear and stress responses but in some research, it significantly increases feather pecking over age during the production phase. UVB light will significantly improve skeletal health, but an optimum duration of exposure is necessary to get this benefit. Supplementation with UVB light may have more distinct impacts on egg production and eggshell quality when hens are experiencing a dietary vitamin $D_{3}$ deficiency, or if they are at the terminal end of production. The relative benefits of UVB supplementation across different ages needs to be further verified along with commercial trials to confirm beneficial or detrimental impacts of adding UVA wavelengths. Further research is warranted to determine whether adding natural light wavelengths to indoor poultry production is indeed a positive step toward optimizing commercial housing systems.

Keywords: laying hen, behavior, broiler, welfare, chicken, skeletal health, UV light

\section{INTRODUCTION}

Light is an important component of poultry housing systems as it can affect a bird's behavior, growth, health, production performance, reproduction, and welfare (Lewis and Morris, 1998; Wineland, 2002). There are a range of factors aligning with lighting effects on poultry including the source of light, level of intensity, duration (photoperiod), and color (wavelengths) and all have 
distinct effects on the bird (Manser, 1996; Lewis and Morris, 2000; Prescott et al., 2003). With increasing sophistication of poultry housing systems to optimize productivity and bird welfare and improve system sustainability, the environment that the birds experience and its consequent impacts must be understood. Housing modifications that enhance the system's output and/or bird welfare for the advancement of the poultry industry are continually being sought. In terms of lighting, supplemental ultraviolet (UV) wavelengths may be an avenue for improvement.

Avian vision has greater spectral sensitivity than that of humans, and poultry can see light in the UV spectrum (Bowmaker et al., 1997; Prescott and Wathes, 1999; Rajchard, 2009) as well as experience physiological effects on vitamin D, similar to humans (Engelsen, 2010; Vergneau-Grosset and Péron, 2020). UV light comprises the shorter wavelengths (100-400 nm) of the electromagnetic radiation spectrum and is divided into three distinct parts: UVA (315-400 nm), UVB (280-315 nm), and UVC (100-280 nm). The visual perception of a poultry eye lens to radiation between 320 and $400 \mathrm{~nm}$ allows them to see UVA light (Govardovskii and Zueva, 1977; Hart et al., 1999; Hunt et al., 2009). Retinally perceived UVA spectrum in poultry is also transmitted to pineal oscillators which controls the circadian rhythm through regulation of melatonin secretion in the pineal gland (Rosiak and Zawilska, 2005).

UVB plays a key role in the production of vitamin $\mathrm{D}_{3}$ which promotes intestinal absorption of calcium and phosphorus, thus increasing bone mineralization and development of skeletal health (DeLuca, 2004; de Matos, 2008). In poultry, the main sources of vitamin $D_{3}$ are the endogenous synthesis in the skin by irradiation of UVB light and the dietary intake of animal origin feed stuffs (Ameenuddin et al., 1985; Tian et al., 1994; Stanford, 2006). A biochemical structure in the form of 7-Dehydrocholesterol (7-DHC) (provitamin $\mathrm{D}_{3}$ ) present in the epidermis of the skin, is converted into previtamin $\mathrm{D}_{3}$ by ultraviolet UVB light. The concentration of 7-DHC is 30 times greater on the featherless leg skin than the back skin (Tian et al., 1994), and 190-fold higher compared to the comb (Schutkowski et al., 2013). Through physiological pathways, the previtamin $\mathrm{D}_{3}$ is converted to the biologically active form of vitamin $\mathrm{D}_{3}$, also known as calcitriol and acts like a hormone contributing to calcium regulation [further details of the pathway have been described by de Matos (2008) and the role of UV in poultry is summarized in Figure 1]. However, excessive exposure to UVB radiation can also destroy vitamin $\mathrm{A}$ in the skin, damage collagen fibers, cause sunburn and initiate detrimental molecular changes in the skin (McKenzie et al., 2003; Lewis and Gous, 2009). The UVC wavelengths are hazardous to both humans and animals and are only used in poultry production for germicidal purposes.

UV light (UVA and UVB) may thus be important for poultry production in commercial systems to improve behavior and health such as through increasing the frequencies of desirable behaviors (e.g., foraging) and decreasing frequencies of undesirable behaviors (e.g., aggressive feather pecking) that can lead to injury, but it is not yet widely used. Historically, incandescent and sodium vapor lights were used for poultry farming, followed by fluorescent lighting. Currently, lightemitting diodes (LED) are widely used for commercial poultry industries (Benson et al., 2013; Parvin et al., 2014) but they are devoid of the UV spectrum. With consumers driving improvements in animal welfare, housing systems must cater to bird needs as well as being sustainable, thus requiring environmental optimization. The provision of UV light has garnered increasing interest with recent reviews highlighting the potential benefits for extending the commercial hen laying cycle (England and Ruhnke, 2020), and for enhancing vitamin D content in eggs for human health (Barnkob et al., 2020). Access to UV light is also more natural for poultry which may align with consumers" views that a more "natural" environment is better for bird welfare (Schröder and McEachern, 2004; Vanhonacker and Verbeke, 2014; Pettersson et al., 2016). This view extends to the increases in free-range poultry systems (Scrinis et al., 2017) where access to daylight/sunlight is one factor considered important by consumers (de Jonge and van Trijp, 2013). Free-range systems may be most optimal for birds to receive adequate UV light both behaviorally and physiologically. However, globally, there is still a large proportion of the poultry industry that uses intensive indoor farming, and thus artificial illumination with UV supplementation may be beneficial. Alternatively, more natural light wavelengths may not be suitable for intensively farmed birds where many other factors of their environment and social structure are different to what would be experienced by their wild counterparts. There have been an increasing number of research publications related to the provision of UV light for poultry (approximately 17 papers in the past 5 years compared with 7 in the 5 years prior), and some poultry-specific bulbs that include UVA wavelengths being developed. Thus, this review is a timely summary of the most recent information about the effects of UV light on poultry behavior, welfare, health, and production in chickens and other poultry species, providing a better understanding of its implication in poultry industries and directions for future research.

\section{EFFECTS OF UV LIGHT ON LAYING HENS (INCLUDING BREEDER BIRDS)}

\section{Behavior and Welfare}

The retina of avian species allows visual perception of UVA wavelengths and these may be critical for bird orientation, social signaling and foraging decisions (Cuthill et al., 2000). Hens can see UVA light and the presence or absence of these wavelengths has been shown to influence fearfulness, feeding behavior, mate selection, mating activity, social interactions and locomotion behaviors as summarized in Table $\mathbf{1}$. When given a choice, chicks have been shown to prefer an area with 15\% UVA where lower percentages of UVA supplementation reduced the strength of the preference (Liu et al., 2018). Similarly, Rana et al. (2021) demonstrated that individually-tested laying hens of 44 weeks of age preferred a medium intensity of UVA light, and both low and medium intensity of the light containing UVA plus UVB wavelengths (UVA/B) over the standard indoor LED white lighting. The domestic chickens' ancestors were the red jungle 


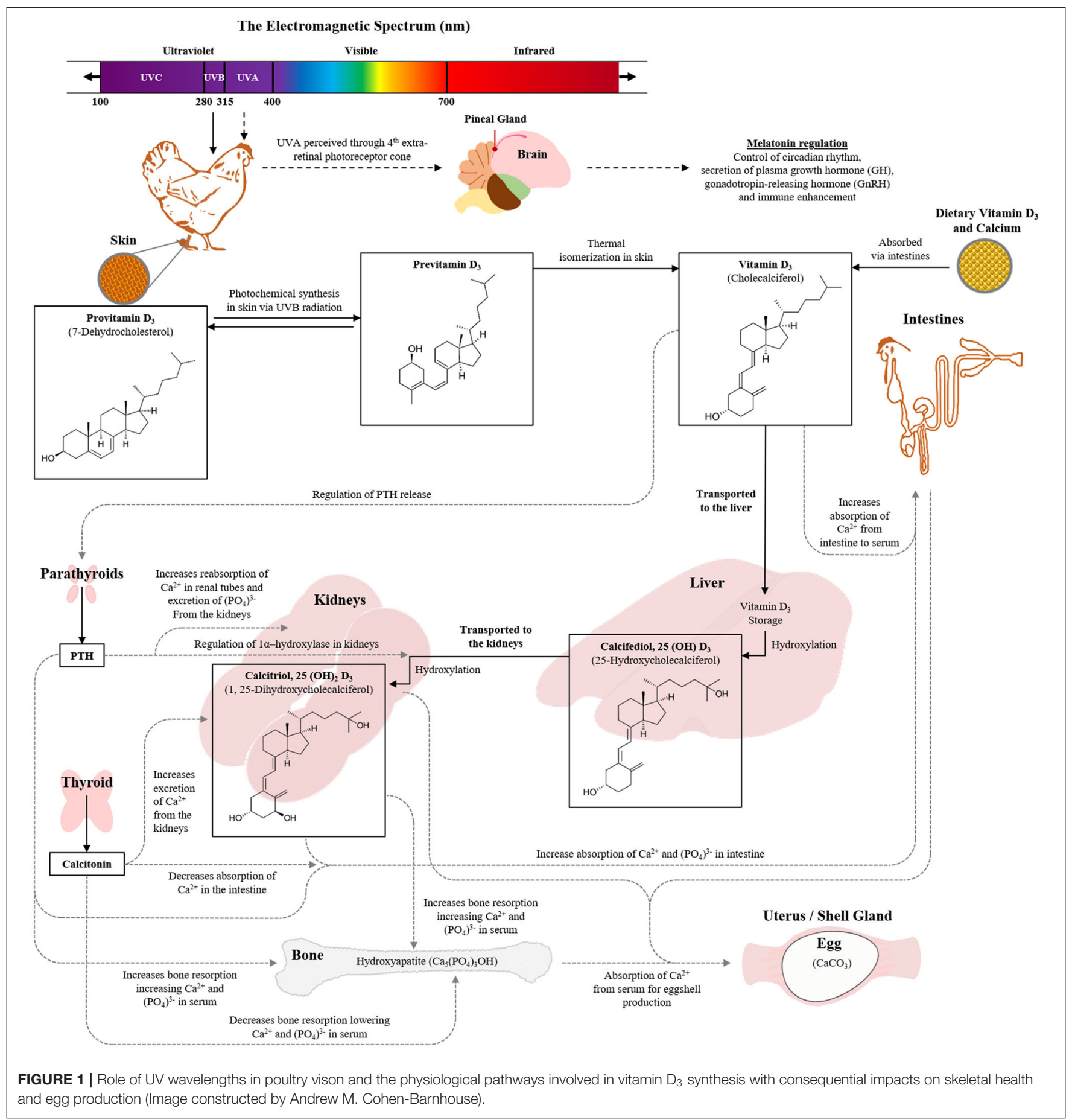

fowl, which typically lived in forest understory with exposure to a more filtered lighting environment distinct from a full daylight spectrum (Wichman et al., 2021). In assessment of hen behavior under forest (with UV), daylight (with UV), and control lighting (without UV), there were more active behaviors (e.g., foraging, locomotion, perching) expressed in UVA-containing over the UVA-deficient lighting environment and birds preferred forest over control lighting when given a choice (Wichman et al., 2021). However, no differences were observed across many other behavioral measures taken in the home pens indicating the preferences were subtle and the control lighting was not aversive (Wichman et al., 2021). Previously, the optimum level of UVA supplementation that improved comfort behaviors (e.g., dust bathing and preening), and reduced fearfulness was reported to be $13-20 \%$ UVA output in the total capacity of fluorescent lighting (Ruis et al., 2010). Rana et al. (2021) also demonstrated 
TABLE 1 | Effects of UV light on laying hen behavior and welfare.

\begin{tabular}{|c|c|c|c|c|c|}
\hline References & $\begin{array}{l}\text { Strain (housing } \\
\text { type) }\end{array}$ & $\begin{array}{l}\text { Age } \\
\text { (wk) }\end{array}$ & Light treatments ${ }^{a}$ & Light intensity ${ }^{b}$ & Behavior and welfare observations \\
\hline $\begin{array}{l}\text { Wichman et al. } \\
\text { (2021) }\end{array}$ & $\begin{array}{l}\text { Bovans Robust } \\
\text { (experimental floor } \\
\text { pens including } \\
\text { choice pens) }\end{array}$ & $0-27$ & $\begin{array}{l}\text { - LED white } \\
\text { - LED white + UVA } \\
\text { (daylight) } \\
\text { - RGB LED + UVA } \\
\text { (forest light) }\end{array}$ & $\begin{array}{l}7.9 \pm 1.0,10.9 \pm 1.4, \text { and } \\
8.3 \pm 0.05 \text { lux, respectively }\end{array}$ & $\begin{array}{l}\text { - Birds preferred forest light over the LED white } \\
\text { lighting } \\
\text { - More active behaviors (foraging, locomotion, } \\
\text { and standing) were observed in daylight } \\
\text { and forest light than LED white light during } \\
\text { preference tests. But no behavioral differences } \\
\text { observed in the home pens } \\
\text { - Birds under daylight had better plumage than } \\
\text { birds under forest light }\end{array}$ \\
\hline Rana et al. (2021) & $\begin{array}{l}\text { ISA Brown } \\
\text { (choice chambers) }\end{array}$ & $44-53$ & $\begin{array}{l}\text { - LED white vs. LED white } \\
\text { + VIS ( } 2 \text { h) } \\
\text { - LED white vs. LED white } \\
\text { + UVA (2 h) } \\
\text { - LED white vs. LED white } \\
\text { + UVA/B (2 h) }\end{array}$ & $\begin{array}{l}20.3 \pm 2.1 \text { lux for LED white } \\
\text { as control, and LED }+ \text { VIS, } \\
\text { LED + UVA, and LED + } \\
\text { UVA B were tested at low, } \\
\text { medium and high intensities } \\
\text { over the LED white }\end{array}$ & $\begin{array}{l}\text { - Hens spent more time under the UV } \\
\text { supplemented LED light over the UV-deficient } \\
\text { LED light } \\
\text { - Birds had preferences for both low intensity } \\
\text { of LED + UVA/B and LED + VIS light, } \\
\text { medium intensity of both UVA and UVA/B } \\
\text { supplemented LED light over LED white } \\
\text { - More foraging, preening and ground pecking } \\
\text { behaviors were observed under low intensity } \\
\text { of LED + UVA/B light, but feed intake } \\
\text { decreased under LED + UVA light treatments }\end{array}$ \\
\hline $\begin{array}{l}\text { Sobotik et al. } \\
(2020)\end{array}$ & $\begin{array}{l}\text { White Leghorn } \\
\text { (commercial-style } \\
\text { cage) }\end{array}$ & $18-72$ & $\begin{array}{l}\text { - LED (white and red) } \\
\text { - LED + UVA }\end{array}$ & $\begin{array}{l}4 \text { foot-candles at feeder } \\
\text { level }\end{array}$ & $\begin{array}{l}\text { - LED + UVA reduced fear behaviors and } \\
\text { physiological stress parameters }\end{array}$ \\
\hline $\begin{array}{l}\text { Spindler et al. } \\
\text { (2020) }\end{array}$ & $\begin{array}{l}\text { Lohmann Brown } \\
\text { (commercial } \\
\text { aviary) }\end{array}$ & $1-48$ & $\begin{array}{l}\text { - } \mathrm{FL} \\
\text { - } \mathrm{FL}+\text { UVA (4-5\%) }\end{array}$ & $\begin{array}{l}\text { Rearing phase, both } \\
\text { treatments (1-6 wk): 25-28 } \\
\text { lux } \\
\text { Growing phase, both } \\
\text { treatments ( } 7-17 \text { wk): } \\
25-27 \text { lux } \\
\text { Laying phase, both } \\
\text { treatments ( } 18-25 \text { wk): } \\
60-64 \text { lux } \\
\text { Production phase, both } \\
\text { treatments ( } 27-48 \text { wk): light } \\
\text { intensity gradually reduced } \\
\text { to } 2.4 \text { lux until } 48 \text { week then } \\
\text { UVA lights were turned off }\end{array}$ & $\begin{array}{l}\text { - FL + UVA did not affect plumage condition } \\
\text { until hens started laying } \\
\text { - Plumage damage increased steadily with age } \\
\text { due to increasing feather pecking behaviors } \\
\text { and skin injuries in FL + UVA hens during the } \\
\text { production phase }\end{array}$ \\
\hline Liu et al. (2018) & $\begin{array}{l}\text { White Leghorn } \\
\text { (choice chambers) }\end{array}$ & $\begin{array}{l}\text { Day } \\
\text { old-8 } \\
\text { days }\end{array}$ & $\begin{array}{l}\text { - LED Dim-to-Blue vs. LED } \\
\text { + UVA (5\%) } \\
\text { - LED Dim-to-Blue vs. LED } \\
\text { + UVA (10\%) } \\
\text { - LED Dim-to-Blue vs. LED } \\
\text { + UVA (15\%) }\end{array}$ & $\begin{array}{l}\text { Day 1-3: } 30-50 \text { lux } \\
\text { Day 4-7: 30-50 lux } \\
\text { Day 8: } 25 \text { lux }\end{array}$ & $\begin{array}{l}\text { - Chicks spent a greater amount of time under } \\
\text { LED + UVA (15\%), least under LED + UVA } \\
\text { (5\%), and comparable time was spent under } \\
\text { LED + UVA (10\%) relative to control lighting } \\
\text { - Feed intake increased under LED + UVA } \\
\text { (15\%) relative to control lighting }\end{array}$ \\
\hline $\begin{array}{l}\text { Schutkowski et al. } \\
\text { (2013) }\end{array}$ & $\begin{array}{l}\text { Lohmann Brown } \\
\text { (experimental } \\
\text { cages) }\end{array}$ & $27-33$ & $\begin{aligned} & -\left(-V i t D_{3}\right)+(-U V B) \\
- & \left(+V i t D_{3}\right)+(-U V B) \\
- & \left(-V i t D_{3}\right)+(+U V B 8 \% \\
& 3 h) \\
- & \left(+V i t D_{3}\right)+(+U V B \\
& 8 \%, 3 h)\end{aligned}$ & $\begin{array}{l}30 \text { lux, } 76 \mu \mathrm{W} / \mathrm{cm}^{2} \mathrm{UVB} \\
\text { irradiance intensity at a } \\
\text { distance of } 20 \mathrm{~cm}\end{array}$ & $\begin{array}{l}\text { - Both UVB light and/or dietary vitamin } \mathrm{D}_{3} \text { did } \\
\text { not affect daily food intake, and no behavioral } \\
\text { abnormalities were observed due to UVB } \\
\text { exposure }\end{array}$ \\
\hline $\begin{array}{l}\text { Lietzow et al. } \\
\text { (2012) }\end{array}$ & $\begin{array}{l}\text { Lohmann White } \\
\text { (experimental } \\
\text { cages) }\end{array}$ & $36-42$ & $\begin{array}{l}\text { - }\left(- \text { Vit } \mathrm{D}_{3}\right)+(-\mathrm{UVB}) \\
\text { - }\left(- \text { Vit } \mathrm{D}_{3}\right)+(+\mathrm{UVB}, 1 \mathrm{~h}) \\
\text { - }\left(+ \text { Vit } \mathrm{D}_{3}\right)+(-\mathrm{UVB}) \\
\left(+ \text { Vit } \mathrm{D}_{3}\right)+(+\mathrm{UVB}, 1 \mathrm{~h})\end{array}$ & $\begin{array}{l}20-30 \text { lux, } 15 \mu \mathrm{W} / \mathrm{cm}^{2} \text { UVB } \\
\text { irradiance intensity at a } \\
\text { distance of } 50 \mathrm{~cm}\end{array}$ & $\begin{array}{l}\text { - Dietary vitamin } D_{3} \text { and UVB exposure } \\
\text { treatments did not affect daily food intake, } \\
\text { however, feed intake decreased under the } \\
\left(- \text { Vit }_{3}\right)+(-U V B) \text { treatment group }\end{array}$ \\
\hline
\end{tabular}


TABLE 1 | Continued

\begin{tabular}{|c|c|c|c|c|c|}
\hline References & $\begin{array}{l}\text { Strain (housing } \\
\text { type) }\end{array}$ & $\begin{array}{l}\text { Age } \\
(w k)\end{array}$ & Light treatments ${ }^{a}$ & Light intensity ${ }^{b}$ & Behavior and welfare observations \\
\hline $\begin{array}{l}\text { Gongruttananun } \\
\text { (2011) }\end{array}$ & $\begin{array}{l}\text { Thai-native } \\
\text { (experimental floor } \\
\text { pens) }\end{array}$ & $18-44$ & $\begin{array}{l}\text { - } \mathrm{DL}+\mathrm{FL}(4 \mathrm{~h}) \\
\text { - } \mathrm{DL}+\mathrm{LED} \text { Red }(4 \mathrm{~h}) \\
\text { - LED Red }\end{array}$ & $\begin{array}{l}583.4,440.2 \text {, and } 74.2 \text { lux, } \\
\text { respectively }\end{array}$ & $\begin{array}{l}\text { - Light treatments had no effect on daily feed } \\
\text { intake }\end{array}$ \\
\hline $\begin{array}{l}\text { Maddocks et al. } \\
\text { (2001) }\end{array}$ & $\begin{array}{l}\text { Lohmann } \\
\text { (experimental floor } \\
\text { pens) }\end{array}$ & $\begin{array}{l}\text { Day } \\
\text { old-28 } \\
\text { days }\end{array}$ & $\begin{array}{l}\text { - IL (halogen bulb) } \\
\text { - IL (halogen bulbs) + UVA }\end{array}$ & - & $\begin{array}{l}\text { - Higher basal corticosterone levels under IL } \\
\text { light than under IL + UVA } \\
\text { - Birds tended to perform more exploratory } \\
\text { behaviors under IL + UVA }\end{array}$ \\
\hline \multirow[t]{2}{*}{$\begin{array}{l}\text { Jones et al. (2001) } \\
\text { (2 experiments) }\end{array}$} & $\begin{array}{l}\text { Ross } 508 \text { Broiler } \\
\text { breeder } \\
\text { (experimental floor } \\
\text { pens) }\end{array}$ & 29-34 & $\begin{array}{l}\text { - } \mathrm{FL} \\
\text { - } \mathrm{FL}+\text { UVA (16.9\%) }\end{array}$ & 50-70 lux & $\begin{array}{l}\text { - FL + UVA lighting environment increased } \\
\text { birds' mating attempts and locomotor activity }\end{array}$ \\
\hline & $\begin{array}{l}\text { Ross } 508 \text { Broiler } \\
\text { breeder } \\
\text { (mate choice } \\
\text { maze) }\end{array}$ & 28-? & $\begin{array}{l}\text { - } F L+\text { UVA }(1.6 \%) \\
\text { - } F L+\text { UVA }(14.6 \%) \\
\text { - } F L+\text { UVA }(43.5 \%) \\
\text { - } F L+\text { UVA }(57.5 \%)\end{array}$ & 50-70 lux & $\begin{array}{l}\text { - The amount of UVA light affected the time } \\
\text { hens spent inspecting cockerels }\end{array}$ \\
\hline $\begin{array}{l}\text { Lewis et al. } \\
\text { (2000b) }\end{array}$ & $\begin{array}{l}\text { ISA Brown } \\
\text { (experimental } \\
\text { cages) }\end{array}$ & $25-29$ & $\begin{array}{l}\text { - } \mathrm{IL}(16 \mathrm{~h}) \\
\text { - } \mathrm{IL}(8 \mathrm{~h})+\mathrm{UVA} / \mathrm{B}(00: 00 \text { to } \\
\text { 12:00, 8h) } \\
\text { - } \mathrm{IL}(8 \mathrm{~h})+\text { UVAVB (12:00 to } \\
\text { 24:00, 8h) }\end{array}$ & $\begin{array}{l}4.9,7.4 \text {, and } 8.8 \text { lux and UV } \\
\text { irradiance intensity (between } \\
\text { source and feed trough) } \\
0.09,0.13 \text {, and } 0.19 \mathrm{~W} / \mathrm{m}^{2} \\
\text { (at bottom, middle, top tiers, } \\
\text { respectively) }\end{array}$ & $\begin{array}{l}\text { - Daily food intake was suppressed under } \\
\text { UVA/B supplemented lighting conditions } \\
\text { compared to IL }\end{array}$ \\
\hline
\end{tabular}

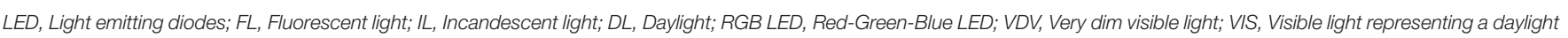

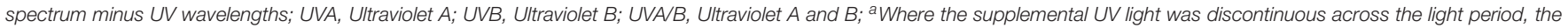

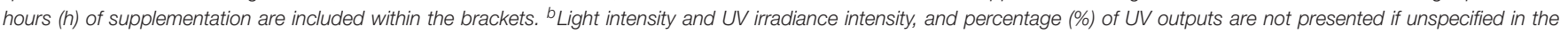
original paper. ? indicates that this information was not found in the reviewed study.

greater foraging and preening behaviors under a low intensity of UVA/B light during individual preference testing.

In an experimental context, Maddocks et al. (2001) showed that day-old layer chicks reared up to 28 days with UVA supplementation, showed a trend of more exploratory behaviors such as ground scratching and environmental pecking than the birds under UVA-deficient lighting. Furthermore, these supplemented birds had significantly lower basal plasma corticosterone concentrations, although all birds reached the same corticosterone peak under a capture-handling-restraint procedure (Maddocks et al., 2001). Consistent with these findings, Sobotik et al. (2020) showed that adult cage-housed hens supplemented with UVA light also had lower basal plasma corticosterone concentrations at 40 and 72 weeks of age and lower heterophil/lymphocyte ratios compared with control (nonsupplemented) hens. Furthermore, at 44 and 72 weeks of age, the UVA supplemented hens showed lower fear responses in behavioral tests of tonic immobility and inversion (Sobotik et al., 2020).

UVA supplementation has been demonstrated to reduce pullet feed intake in some research (Lewis et al., 2000b), but increase chick feed intake (Liu et al., 2018) and UVB light has had no feed intake effect in other studies (Gongruttananun, 2011; Lietzow et al., 2012; Schutkowski et al., 2013). Jones et al. (2001) observed an effect of UVA radiation on mating and locomotor activity of broiler breeders, and female broiler breeders spent more time inspecting cockerels under the UVA-supplemented lighting environment. Thus, the absence of UV light in typical indoor housing systems may impact on bird welfare.
In contrast, UVA light has shown some negative effects on laying hens' behaviors. For example, increased feather pecking and skin pecking leading to plumage damage and cannibalism was observed in UV-supplemented commercial aviary-housed non-beak-trimmed hens during the production phase (Spindler et al., 2020). As a result, the UV supplementation had to be discontinued, although no pecking damage was observed under the UVA supplementation during the rearing period (Spindler et al., 2020). The feather pecking behaviors during the production cycle could have resulted from the UVA light making the feathers of conspecifics look more attractive than under standard lighting. It is also possible that the specific intensities of the included UV wavelengths were not optimal, warranting further testing with poultry specific UVA bulbs. In an experimental floor-pen context, adult hens exposed to full spectrum bulbs (containing UVA), UVB bulbs or standard control lighting across 6 weeks showed no treatment differences in feather condition (Kühn et al., 2019). Additionally hens did not actively avoid pen areas with the UVB exposure, suggesting UVA and/or a desired amount of UVB exposure for a certain duration may have no adverse effect on hen behavior and welfare (Kühn et al., 2019). Therefore, ensuring the optimum level of UV supplementation in intensive poultry farming is still a challenge. A certain level of UVA light might improve laying hen behavior and welfare but any negative consequences on feather pecking behavior would have to be managed. The amount of UV output, level of intensity, and duration of UV light supplementation across different bird ages and production stages needs to be further explored in both experimental and commercial settings. 


\section{Body Growth, Physiology, and Skeletal Health}

Long bone non-infectious disease (e.g., osteoporosis) is a significant problem in laying hen industries, particularly during the later phase of laying cycle, and in cage-housed hens (Whitehead and Fleming, 2000; Webster, 2004). Keel bone damage is a prominent welfare concern for hens within alternative, loose-housed systems (Campbell, 2020; Rufener and Makagon, 2020). Sub-optimal growth, leg weakness (e.g., rickets), and low mineral contents (e.g., calcium and phosphorus) in the blood are the signs of a vitamin $\mathrm{D}_{3}$ deficiency in young chickens (Atencio et al., 2005). The benefits of UVB radiation for its physiological role in converting 7-DHC to cholecalciferol (Vit$\mathrm{D}_{3}$ ) in the skin of the feet, comb, and wattles of layer chickens (de Matos, 2008; Schutkowski et al., 2013 and see Figure 1) could minimize the risk of skeletal disorders but evidence with laying hens to date is limited.

The effects of UV lights on growth and physiology, and skeletal health in laying hens are summarized in Table 2. A recent trial across a production cycle on a commercial laying hen farm found that the mean body weights of hens under fluorescent light (FL) were heavier than under a FL+UVA light treatment across the weeks of the trial although the supplementation had to be removed prematurely due to its impact on feather pecking behavior (see section Behavior and Welfare: Spindler et al., 2020). Lietzow et al. (2012) also reported higher body weight in hens exposed to UVB but only in those birds that were also fed an adequate vitamin $\mathrm{D}_{3}$ diet compared with other treatment groups in a dietary vitamin $\mathrm{D}_{3} / \mathrm{UVB}$ supplementation two-way experimental design. In contrast, other studies have reported no significant effects of either daylight or specifically UVB light exposure on daily body weight gain (Gongruttananun, 2011; Schutkowski et al., 2013; Kühn et al., 2015). Body weight alone in meat birds is a stronger indicative measure than in laying hens and in the aforementioned studies, multiple other measures were taken in addition to body weight to quantify the lighting impacts (see sections Behavior and Welfare and Egg Production and Egg Quality).

Research into UV impacts on skeletal health for hens found that UVB exposure of 2 or $3 \mathrm{~h}$ daily increased the bone mineral density of older laying hens relative to only $1 \mathrm{~h}$ or no UVB supplementation (Wei et al., 2020). However, effects on bone area and bone mineral content were inconsistent among treatment groups across age (Wei et al., 2020). Assessment of serum samples showed no impacts across the 8-week trial duration on $25(\mathrm{OH}) \mathrm{D}_{3}$ and $\mathrm{P}$ changes across time were similar across all treatment groups (Wei et al., 2020). UVB did affect the $\mathrm{Ca}$ and $1,25(\mathrm{OH})_{2} \mathrm{D}_{3}$ values relative to the control group and 7 -DHC was significantly reduced across all durations of UVB exposure indicating a reduced 7-DHC content in the skin to be synthesized by UVB radiation across time (Wei et al., 2020; see Figure 1 for an explanation of the vitamin D pathway). Schutkowski et al. (2013) also found no impact of $3 \mathrm{~h}$ daily UVB radiation on plasma $\mathrm{Ca}$ and inorganic phosphate concentrations. The UVB radiation did increase plasma concentrations of $1,25(\mathrm{OH})_{2} \mathrm{D}_{3}$ but $25(\mathrm{OH}) \mathrm{D}_{3}$ was only increased in birds that were fed a vitamin
$\mathrm{D}_{3}$-deficient diet, with similar diet/light interactive effects on tibial breaking strength (Schutkowski et al., 2013). An additional study showed that dietary vitamin $\mathrm{D}_{3}$ had a significant effect on the plasma concentrations of $25(\mathrm{OH}) \mathrm{D}_{3}, 1,25(\mathrm{OH})_{2} \mathrm{D}_{3}$, and $\mathrm{Ca}$; but an additional $1 \mathrm{~h}$ daily UVB supplementation could only slightly (not significantly) improve the $25(\mathrm{OH}) \mathrm{D}_{3}$ content (Lietzow et al., 2012). Kühn et al. (2015) observed no impact of varying UVB exposure durations on plasma concentrations of $1,25(\mathrm{OH})_{2} \mathrm{D}_{3}$ or the precursor 7 -DHC relative to no UVB exposure and only a trend for an increase in $25(\mathrm{OH}) \mathrm{D}_{3}$. There was an increase in vitamin $\mathrm{D}_{3}$ contents over UVB exposure time in unfeathered leg skin, but with no exposure duration effects on 7-DHC in skin tissue (Kühn et al., 2015). Overall, UVA light may not play an extensive role in laying hen growth and physiology (but see sections Behavior and Welfare and Egg Production and Egg Quality), but UVB light could have benefits on skeletal health and vitamin $\mathrm{D}_{3}$ synthesis in the body. These effects may be most prominent toward the end of the production cycle when there is more strain on the hen's body from continuous weeks of egg laying. However, this would require more research as evidence at the terminal phase of the laying cycle is currently limited. Furthermore, in commercial layer industries, particularly for the loose housing systems, keel bone damage still remains as one of the major welfare concerns (Wilkins et al., 2011; Petrik et al., 2015). Research is growing around potential solutions for preventing adult keel bone damage by improving skeletal health during the pullet phase (Regmi et al., 2015; Casey-Trott et al., 2017). Harlander-Matauschek et al. (2015) presented suggestions for future research considerations in the prevention of keel bone damage including investigating dietary supplementation. Although, dietary vitamin $\mathrm{D}_{3}$ and its metabolites have not yet shown a contributory effect in improving keel bone damage (Käppeli et al., 2011; Wen et al., 2019), the studies are limited, particularly in regard to the UVB impacts on vitamin $\mathrm{D}_{3}$ and keel bone health. Therefore, it is suggested that further research determines if UVB light could have an effect on preventing keel bone deformities in laying hens.

\section{Egg Production and Egg Quality}

Light has a key stimulatory effect in initiating the ovulatory cycle in poultry via extra-retinal photoreceptors in the hypothalamus that trigger the gonadotropin-releasing hormones (GnRH-I and GnRH-II) (Bédécarrats, 2015). Longer wavelengths of red light are specifically critical for stimulating the GnRH release (Reddy et al., 2012; Baxter et al., 2014) and darkness produces melatonin to stimulate the gonadotropin inhibitory hormone $(\mathrm{GnIH})$ that prevents GnRH release (Tsutsui et al., 2000, 2010). However, as reviewed by Hanlon et al. (2020), light is not the only factor triggering reproductive status within hens, other metabolic factors may also play an important role.

On a molecular level, chickens have opsin receptors in the brain that are sensitive to UV wavelengths (Yamashita et al., 2010) but the specific role of UV in controlling a photoperiodic response is unclear (García-Fernández et al., 2015), particularly given the poorer cranial penetration of these shorter wavelengths (Foster and Follett, 1985; Lewis and 
TABLE 2 | Effects of UV light on growth, physiology, and skeletal health of laying hens.

\begin{tabular}{|c|c|c|c|c|c|}
\hline References & $\begin{array}{l}\text { Strain (housing } \\
\text { type) }\end{array}$ & $\begin{array}{l}\text { Age } \\
\text { (wk) }\end{array}$ & Light treatments ${ }^{a}$ & Light intensityb & $\begin{array}{l}\text { Health, growth, and physiological } \\
\text { observations }\end{array}$ \\
\hline Wei et al. (2020) & $\begin{array}{l}\text { Jingfen } \\
\text { (experimental } \\
\text { cages) }\end{array}$ & $68-75$ & $\begin{array}{l}\text { - LED white } \\
\text { - LED + UVB (1 h) } \\
\text { - LED + UVB ( } 2 \text { h) } \\
\text { - LED + UVB (3 h) }\end{array}$ & $\begin{array}{l}15 \text { lux and } 27 \mu \text { W UVB } \\
\text { irradiance intensity at a } \\
\text { distance of } 20 \mathrm{~cm}\end{array}$ & $\begin{array}{l}\text { - Bone mineral density of hens decreased } \\
\text { over time (age) under LED white light, but } \\
\text { significantly increased with LED + UVB ( } 2 \mathrm{~h}) \\
\text { and LED + UVB ( } 3 \mathrm{~h} \text { ) lights } \\
\text { - } 7 \text {-DHC was significantly reduced across all } \\
\text { durations of UVB exposure relative to the } \\
\text { control group but no significant changes in } \\
\text { plasma } \mathrm{Ca}, \mathrm{P}, 1,25(\mathrm{OH})_{2} \mathrm{D}_{3} \text {, or } 25(\mathrm{OH}) \mathrm{D}_{3}\end{array}$ \\
\hline $\begin{array}{l}\text { Spindler et al. } \\
\text { (2020) }\end{array}$ & $\begin{array}{l}\text { Lohmann Brown } \\
\text { (commercial } \\
\text { aviary) }\end{array}$ & $1-48$ & $\begin{array}{l}\text { - } \mathrm{FL} \\
\text { - } \mathrm{FL}+\text { UVA (4-5\%) }\end{array}$ & $\begin{array}{l}\text { Rearing phase, both } \\
\text { treatments ( } 1-6 \mathrm{wk}): 25-28 \\
\text { lux } \\
\text { Growing phase, both } \\
\text { treatments ( } 7-17 \mathrm{wk}) \text { : } \\
25-27 \text { lux } \\
\text { Laying phase, both } \\
\text { treatments (18-25 wk): } \\
60-64 \text { lux } \\
\text { Production phase, both } \\
\text { treatments ( } 27-48 \text { wk): light } \\
\text { intensity gradually reduced } \\
\text { to } 2.4 \text { lux until } 48 \text { wk then } \\
\text { UVA lights were turned off }\end{array}$ & $\begin{array}{l}\text { - The mean body weights of FL group hens } \\
\text { were heavier than FL + UVA hens across age } \\
\text { during the laying cycle } \\
\text { - The FL group had higher mortality than the } \\
\text { FL + UVA hens }\end{array}$ \\
\hline Kühn et al. (2015) & $\begin{array}{l}\text { Lohmann Brown } \\
\text { (experimental } \\
\text { cages) }\end{array}$ & $26-32$ & $\begin{array}{l}\text { - No UVB (Control) } \\
\text { - Daily UVB (8\%) exposure } \\
\text { of } 15,30,60,120,180 \text {, } \\
\text { and } 300 \text { min }\end{array}$ & $\begin{array}{l}76 \mu \mathrm{W} / \mathrm{cm}^{2} \text { UVB irradiance } \\
\text { intensity at a distance of } \\
20 \mathrm{~cm}\end{array}$ & $\begin{array}{l}\text { - Plasma concentrations of } 1,25(\mathrm{OH})_{2} \mathrm{D}_{3} \text { and } \\
25(\mathrm{OH}) \mathrm{D}_{3} \text {, and } 7 \text {-DHC were not affected by } \\
\text { UVB treatment. There was a strong effect of } \\
\text { UVB exposure on vitamin } \mathrm{D}_{3} \text { in unfeathered } \\
\text { leg skin. UVB did not affect feed intake and } \\
\text { body weight gain }\end{array}$ \\
\hline $\begin{array}{l}\text { Schutkowski et al. } \\
\text { (2013) }\end{array}$ & $\begin{array}{l}\text { Lohmann } \\
\text { (experimental } \\
\text { cages) }\end{array}$ & $27-33$ & $\begin{array}{l}-\left(- \text { Vit } D_{3}\right)+(-U V B) \\
\text { - }\left(+ \text { Vit } D_{3}\right)+(-U V B) \\
\text { - }\left(- \text { Vit } D_{3}\right)+(+ \text { UVB 8\%, } \\
3 \text { h }) \\
\text { - }\left(+ \text { Vit } D_{3}\right)+(+ \text { UVB } \\
8 \%, 3 h)\end{array}$ & $\begin{array}{l}30 \text { lux, } 76 \mu \mathrm{W} / \mathrm{cm}^{2} \text { UVB } \\
\text { irradiance intensity at a } \\
\text { distance of } 20 \mathrm{~cm}\end{array}$ & $\begin{array}{l}\text { - (+)UVB strongly increased the plasma } \\
\text { concentration of } 25(O H) D_{3} \text { in hens fed the (-) } \\
\text { Vit } D_{3} \text { diet but had minimal effect on plasma } \\
1,25(O H)_{2} D_{3} \text { concentrations } \\
\text { - Dietary vitamin } D_{3} \text { and UVB exposure did not } \\
\text { affect Ca and inorganic phosphate plasma } \\
\text { concentrations, but UVB increased vitamin } D_{3} \\
\text { content in skeletal muscle. UVB increased } \\
\text { tibial bone breaking strength in }(-) \text { Vit } D_{3} \text { hens } \\
\text { only } \\
\text { - Both UVB light and/or dietary vitamin } D_{3} \text { did } \\
\text { not affect body weight }\end{array}$ \\
\hline $\begin{array}{l}\text { Lietzow et al. } \\
\text { (2012) }\end{array}$ & $\begin{array}{l}\text { Lohmann White } \\
\text { (experimental } \\
\text { cages) }\end{array}$ & $36-42$ & $\begin{array}{l}\text { - }\left(- \text { Vit } D_{3}\right)+(-U V B) \\
\text { - }\left(- \text { Vit } D_{3}\right)+(+U V B, 1 \mathrm{~h}) \\
\text { - }\left(+ \text { Vit } D_{3}\right)+(-U V B) \\
\text { - }\left(+ \text { Vit } D_{3}\right)+(+U V B, 1 \text { h) }\end{array}$ & $\begin{array}{l}\text { 20-30 lux, } 15 \mu \mathrm{W} / \mathrm{cm}^{2} \text { UVB } \\
\text { irradiance intensity at } \\
\text { distance of } 50 \mathrm{~cm}\end{array}$ & $\begin{array}{l}\text { - Dietary vitamin } D_{3} \text { had a significant effect } \\
\text { on the plasma concentration of } 25(\mathrm{OH}) \mathrm{D}_{3} \text {, } \\
1,25(\mathrm{OH})_{2} \mathrm{D}_{3} \text {, and } \mathrm{Ca} \text {; though additional UVB } \\
\text { slightly improved } 25(\mathrm{OH}) \mathrm{D}_{3} \text { content } \\
\text { - Hens of }\left(+ \text { Vit } \mathrm{D}_{3}\right)+(+\mathrm{UVB}) \text { group had higher } \\
\text { final body weights compared to other groups }\end{array}$ \\
\hline $\begin{array}{l}\text { Gongruttananun } \\
\text { (2011) }\end{array}$ & $\begin{array}{l}\text { Thai-native } \\
\text { (experimental floor } \\
\text { pens) }\end{array}$ & $18-44$ & $\begin{array}{l}\text { - } \mathrm{DL}+\mathrm{FL}(4 \mathrm{~h}) \\
\text { - } \mathrm{DL}+\mathrm{LED} \text { Red (4 h) } \\
\text { - LED Red }\end{array}$ & $\begin{array}{l}583.4,440.2 \text {, and } 74.2 \text { lux, } \\
\text { respectively }\end{array}$ & $\begin{array}{l}\text { - No significant differences in eye morphology } \\
\text { or body weight gain across light treatment } \\
\text { groups }\end{array}$ \\
\hline
\end{tabular}

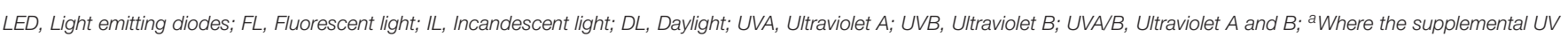

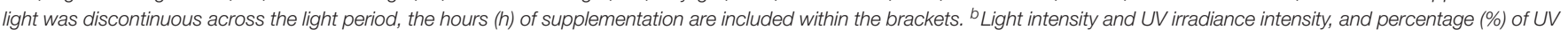
outputs are not presented if unspecified in the original paper.

Gous, 2009). The photoperiodic response is likely controlled by hypothalamic receptors with higher peak absorbances (Davies et al., 2012). This is supported by no significant impacts of UVA/B radiation on oviposition in young sexually mature laying hens (Lewis et al., 2000b) and no impact of natural light exposure on sexual maturity compared with pullets exposed to red light wavelengths (Gongruttananun, 2011). Furthermore, there is limited evidence for effects of UVA and/or UVB supplementation on egg production and egg quality during the laying cycle as summarized in Table 3 and previously reviewed in England and Ruhnke (2020). Across different strains of laying hens, several studies have supplemented with UVA 
TABLE 3 | Effects of UV light on egg production and egg quality.

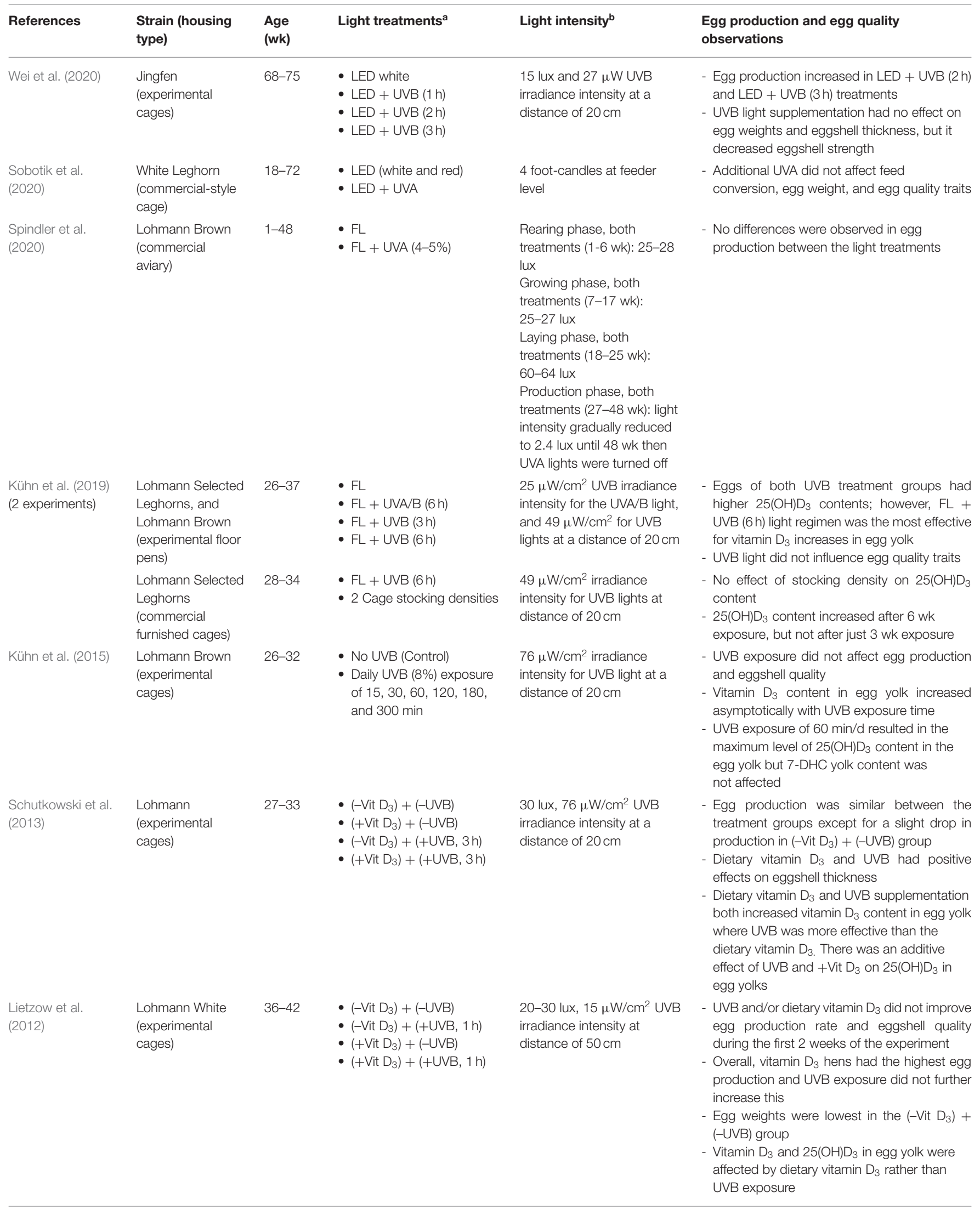


TABLE 3 | Continued

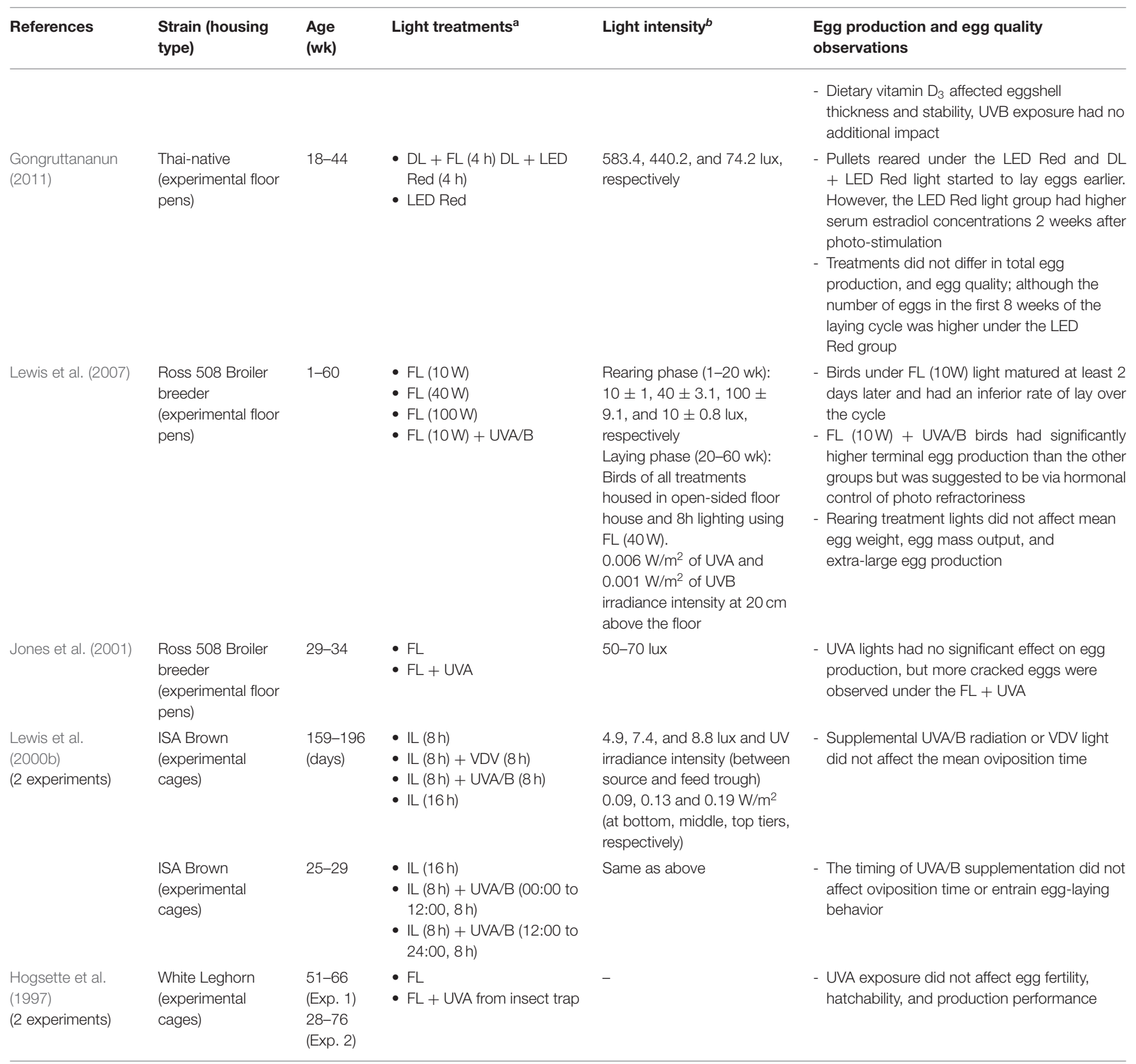

LED, Light emitting diodes; FL, Fluorescent light; IL, Incandescent light; DL, Daylight; VDV, Very dim visible light; UVA, Ultraviolet A; UVB, Ultraviolet B; UVA/B, Ultraviolet A and B; ${ }^{a}$ Where the supplemental UV light was discontinuous across the light period, the hours ( $h$ ) of supplementation are included within the brackets. ${ }^{b}$ Light intensity and UV irradiance intensity, and percentage (\%) of UV outputs are not presented if unspecified in the original paper.

(prototype UV LED bulbs, fluorescent bulbs, or insect light traps), or natural daylight and found no significant impact on egg production, performance, and egg quality traits including egg weight, eggshell breaking strength, eggshell thickness, albumen height, albumen weight, yolk color, yolk height and Haugh units compared with standard lighting (Hogsette et al., 1997; Gongruttananun, 2011; Sobotik et al., 2020; Spindler et al., 2020). Similarly, UVA supplementation in broiler breeders had no significant impact on egg production, although there were more cracked eggs found in the UVA treatment group (Jones et al., 2001).

In contrast, there is some evidence that UVB supplementation does improve terminal egg production and vitamin $\mathrm{D}_{3}$ metabolites in the eggs. The applicable research studies were recently reviewed by England and Ruhnke (2020) and thus will be presented in brief here. As outlined in the introduction, UVB light plays a beneficial role in the synthesis of vitamin $D_{3}$ thereby promoting body absorption of calcium and phosphorus 
to potentially have a beneficial effect on egg production performance and egg quality (Figure 1). Positive impacts of UVB light supplementation on production have been demonstrated in 68 -week-old laying hens where 2 or $3 \mathrm{~h}$ of exposure across 8 weeks increased egg production relative to one or no hours of UVB light supplementation (Wei et al., 2020). However, evidence across previous studies with laying hens in peak to mid production is limited. UVB supplementation has shown no effect on egg production (Schutkowski et al., 2013; Kühn et al., 2015, 2019) or egg weights (Schutkowski et al., 2013). UVB supplementation can compensate for dietary deficiencies which reduce egg production, egg weights, eggshell stability and eggshell thickness (Lietzow et al., 2012; Schutkowski et al., 2013).

In the terminal egg production study by Wei et al. (2020), egg quality traits were not affected by treatment, except eggshell strength decreased with the supplementation, which may have been related to the interplay between calcium allocation to eggshells versus the skeleton (Wei et al., 2020 and see section Body Growth, Physiology, and Skeletal Health). Conversely, positive impacts (or no impact: Kühn et al., 2019) of UVB supplementation, including sunlight exposure on egg shell quality have been demonstrated in other studies using younger hens of different strains (Schutkowski et al., 2013; Kühn et al., 2014) although short-term exposure ( $1 \mathrm{~h}$ daily) may have limited impact beyond what is already provided in the diet (Lietzow et al., 2012). Further support for the impacts of UV on terminal egg production was reported by Lewis et al. (2007) in broiler breeders but this was an impact of UVA exposure during rearing which improved production rate (but not egg weight) between 52 and 60 weeks of age. The UVA exposure during rearing was proposed to have positively affected the bird's responsiveness to photoperiods at later ages (Lewis et al., 2007).

With a focus on human health, hens housed in free-range systems and exposed to sunlight have increased vitamin $\mathrm{D}_{3}$ content in their egg yolks (Kühn et al., 2014). Similarly, vitamin $\mathrm{D}_{3}$ yolk content can also be increased by artificial UVB light supplementation for indoor-housed hens (Schutkowski et al., 2013), although the duration of exposure will determine the presence of and extent of the impact (Lietzow et al., 2012; Kühn et al., 2015, 2019).

Overall, supplementation with specifically UVB light may have the greatest impact on egg production and eggshell quality, but the impacts may be more distinct when hens are experiencing a dietary vitamin $\mathrm{D}_{3}$ deficiency, or if they are at the terminal end of production. Further studies on commercial farms to optimize the dose and daily exposure time are warranted and validate this as a method for producing vitamin $\mathrm{D}_{3}$ enriched eggs for human health benefits.

\section{EFFECTS OF UV LIGHT IN MEAT CHICKENS (EXCLUDING BREEDER BIRDS)}

The majority of commercial meat chicken/broiler production worldwide is based on intensive indoor shed housing (Robins and Phillips, 2011; CIWF, 2019). In these systems, birds experience several housing constraints such as high stocking density, poor air quality, and high moisture in the litter, with welfare issues such as leg health disorders (e.g., rickets, dyschondroplasia, lameness, angular bone deformities, hock burns, and foot pad dermatitis) and compromised behavioral repertoire (Dawkins et al., 2004; Bessei, 2006; Angel, 2007; Averós and Estevez, 2018). While free-range housing is used for both fast- and slow-growing broilers, welfare improvements in conventional intensive indoor production systems remains a focus point in broiler welfare research (Bracke et al., 2019; Rios et al., 2020). A range of lighting factors (i.e., source, intensity, photoperiods, and spectrum) have consequences for broiler production, behavior and welfare (Buyse et al., 1996; Olanrewaju et al., 2006; Soliman and El-Sabrout, 2020). As broiler chickens can also visually perceive UVA spectral light this may be important in their visual communication (Prescott and Wathes, 1999; Kristensen et al., 2007), and UVB light has physiological effects involving vitamin $\mathrm{D}_{3}$ in improving skeletal health (Edwards, 2003; Zhang et al., 2006). Thus, the impacts of UV light on broiler behavior, welfare, and production also need to be considered.

There is a multitude of research on other aspects of broiler lighting systems (Rozenboim et al., 1999; Bailie et al., 2013; Soliman and El-Sabrout, 2020), but few studies have investigated the behavioral, physiological, welfare, and production impacts of UV wavelengths. A summary of the available research to date is presented in Table 4. In radial maze preference testing for varying light sources, broiler chicks at 1 week of age showed no preferences (Kristensen et al., 2007). This preference behavior changed in older birds though with 6-week-old broilers spending more time and performing more behaviors in environments with warm white light and biolux light (small UVA component) over incandescent light and a light designed to most closely match the chickens, spectral sensitivity (included more UVA) (Kristensen et al., 2007). When a different set of birds were housed with these two preferred light sources, birds showed more feather and environment pecking under the biolux light and some increases in wing-flapping but the majority of behaviors were equal across the two light types (Kristensen et al., 2007). Thus, light had an impact on preferences and some behaviors which may have been related to the small UVA component of the biolux light (Kristensen et al., 2007). Contrary to predictions, light with a greater amount of UVA as matched to the birds' spectral sensitivity was not preferred (Kristensen et al., 2007). Physical welfare measures taken from birds under the same two light sources showed no substantial differences between groups in body weight, gait score, footpad dermatitis and hock burns (Kristensen et al., 2006). However, variance in other wavelengths between the two sources reduces conclusions on impacts of UVA alone (Kristensen et al., 2006).

A more recent study on the impacts of specifically UVA supplementation, reared broilers with LED light only or LED light with additional UVA lights (House et al., 2020a). Results across several physiological stress measures and behavioral tests of fear showed the UVA supplementation reduced stress [lower heterophil/lymphocyte $(\mathrm{H} / \mathrm{L})$ ratio, composite asymmetry, and plasma corticosterone] and fear (shorter tonic immobility duration, lower wing flapping during inversion) although there were no effects on immune responses, body weight or feed 
TABLE 4 | Effects of UV light on behavior, growth, and production of meat chickens.

\begin{tabular}{|c|c|c|c|c|c|}
\hline References & $\begin{array}{l}\text { Strain (housing } \\
\text { type) }\end{array}$ & $\begin{array}{l}\text { Age } \\
\text { (days) }\end{array}$ & Light treatments ${ }^{a}$ & Light intensity & $\begin{array}{l}\text { Growth, production, and behavioral } \\
\text { observations }\end{array}$ \\
\hline $\begin{array}{l}\text { House et al. } \\
\text { (2020a) }\end{array}$ & $\begin{array}{l}\text { Cobb } 500 \\
\text { (experimental floor } \\
\text { pens) }\end{array}$ & $1-42$ & $\begin{array}{l}\text { - LED } \\
\text { - LED + UVA }\end{array}$ & $\begin{array}{l}\text { Wk 1: } 20 \text { lux } \\
\text { Wk 2-6: } 5 \text { lux }\end{array}$ & $\begin{array}{l}\text { - Broilers reared under LED + UVA light } \\
\text { showed reduced fear and stress } \\
\text { susceptibility but no effect on growth and } \\
\text { feed conversion ratio }\end{array}$ \\
\hline $\begin{array}{l}\text { James et al. } \\
\text { (2018) and James } \\
\text { et al. (2020) }\end{array}$ & $\begin{array}{l}\text { Ross } 308 \\
\text { (experimental floor } \\
\text { pens) }\end{array}$ & $1-45$ & $\begin{array}{l}\text { - } \text { LED } \\
\text { - } \text { LED + UVA (18 h) } \\
\text { - LED + UVA/B (12\% } \\
\text { UVB, 8h) }\end{array}$ & $\begin{array}{l}19-178.4 \text { clux, } 30 \mu \mathrm{W} / \mathrm{cm}^{2} \\
\text { UVB irradiance intensity at } \\
\text { chick head height }\end{array}$ & $\begin{array}{l}\text { - Broilers under LED + UVA light had improved } \\
\text { feather condition and reduced fearfulness } \\
\text { than under LED; while both LED + UVA and } \\
\text { LED + UVA/B resulted in better gait scores } \\
\text { (improved walking ability) } \\
\text { - Inconsistencies between the UVA and UVA/B } \\
\text { treatment may be related to duration of } \\
\text { exposure } \\
\text { - UVA light decreased mortality and UVA/B } \\
\text { improved growth performance of male } \\
\text { broiler chickens }\end{array}$ \\
\hline $\begin{array}{l}\text { Kristensen et al. } \\
\text { (2007) } \\
\text { ( } 2 \text { experiments) }\end{array}$ & $\begin{array}{l}\text { Ross } 308 \\
\text { (experimental floor } \\
\text { pens and choice } \\
\text { maze) }\end{array}$ & $1-51$ & $\begin{array}{l}\text { - Biolux (similar to daylight } \\
\text { - } \text { with UVA) } \\
\text { Spectral sensitivity } \\
\text { (contains UVA) } \\
\text { - Incandescent } \\
\text { - Warm-white }\end{array}$ & $\begin{array}{l}\text { Exp. 1: } 5 \text { clux (dim) and } 100 \\
\text { clux (bright) per treatment } \\
\text { light (total } 8 \text { light } \\
\text { treatments), } 4 \text { light types } \\
\text { (dim or bright) given in } \\
\text { choice maze }\end{array}$ & $\begin{array}{l}\text { - Birds preferred Biolux and Warm-white light } \\
\text { irrespective of light intensity at } 6 \text { wk of age }\end{array}$ \\
\hline $\begin{array}{l}\text { Edwards (2003) } \\
\text { (A series of } 6 \\
\text { experiments) }\end{array}$ & $\begin{array}{l}\text { Male broilers } \\
\text { (experimental } \\
\text { cages) }\end{array}$ & $1-21$ & $\begin{array}{l}\text { - FL + UVA/B exposure on } \\
\text { different days with various } \\
\text { durations from different } \\
\text { locations (e.g., above and } \\
\text { underneath the birds) } \\
\text { paired with Vit } \\
D_{3} \text {-deficient or adequate } \\
\text { diet }\end{array}$ & - & $\begin{array}{l}\text { - Birds fed with vitamin } D_{3} \text { in diet or exposed to } \\
\text { UVAVB radiation had greater body weight (at } \\
\text { 16-days of age) than the birds fed a vitamin } \\
D_{3} \text { deficient diet } \\
\text { - Chickens with continuous exposure of UVAVB } \\
\text { radiation had increased bone ash, and } \\
\text { decreased incidence of rickets and tibial } \\
\text { dyschondroplasia (TD) than the birds of both } \\
\text { vitamin } D_{3} \text { deficient or enriched diet without } \\
\text { having UVB light exposure } \\
\text { - Birds exposed to UVA/B from day one had } \\
\text { significantly reduced incidence of rickets and } \\
\text { TD than those started } 4 \text { days later }\end{array}$ \\
\hline $\begin{array}{l}\text { Hogsette and } \\
\text { Wilson (1999) }\end{array}$ & $\begin{array}{l}\text { Avian } \times \text { Avian } \\
\text { (experimental floor } \\
\text { pens) }\end{array}$ & $0-42$ & $\begin{array}{l}\text { - } \mathrm{FL} \\
\text { - } \mathrm{FL}+\text { UVA light insect trap }\end{array}$ & - & $\begin{array}{l}\text { - Constant exposure of UVA light did not } \\
\text { adversely affect broiler growth performance, } \\
\text { feed consumption, and mortality }\end{array}$ \\
\hline
\end{tabular}


TABLE 4 | Continued

\begin{tabular}{|c|c|c|c|c|c|}
\hline References & $\begin{array}{l}\text { Strain (housing } \\
\text { type) }\end{array}$ & $\begin{array}{l}\text { Age } \\
\text { (days) }\end{array}$ & Light treatments ${ }^{a}$ & Light intensity ${ }^{b}$ & $\begin{array}{l}\text { Growth, production, and behavioral } \\
\text { observations }\end{array}$ \\
\hline $\begin{array}{l}\text { Elliot and Edwards } \\
\text { (1997) } \\
\text { (A series of } 4 \\
\text { experiments, first } \\
2 \text { used UV light) }\end{array}$ & $\begin{array}{l}\text { Peterson } \times \text { Arbor } \\
\text { Acres } \\
\text { (experimental } \\
\text { cages) }\end{array}$ & $0-16$ & $\begin{array}{l}\text { Exp. } 1 \text { : } \\
\text { - } 2 \times 2 \times 2 \text { factorial }(2 \\
\text { different dietary dosages } \\
\left.\text { of Vit } \mathrm{D}_{3}\right) \\
\text { - } \mathrm{FL}+1,25(\mathrm{OH})_{2} \mathrm{D}_{3} \\
\text { - } \mathrm{FL}+\mathrm{UVA} / \mathrm{B}+ \\
1,25(\mathrm{OH})_{2} \mathrm{D}_{3} \\
\text { - } \mathrm{FL}+1,25(\mathrm{OH})_{2} \mathrm{D}_{3}+\text { Vit } \\
\mathrm{D}_{3} \\
\text { - } \mathrm{FL}+ \\
\mathrm{UVA} \mathrm{B}+1,25(\mathrm{OH})_{2} \mathrm{D}_{3} \\
+\mathrm{Vit} \mathrm{D}_{3} \\
\text { Exp. } 2 \text { : } \\
\text { - } 2 \times 4 \text { factorial }(4 \text { different } \\
\left.\text { dosages of Vit } \mathrm{D}_{3}\right) \\
\text { - } \mathrm{FL}+\text { Vit } \mathrm{D}_{3} \text { (low to high } \\
\text { doses) } \\
\text { - } \mathrm{FL}+\mathrm{UVA} / \mathrm{B}+\mathrm{Vit} \mathrm{D}_{3} \text { (low } \\
\text { to high doses) }\end{array}$ & - & $\begin{array}{l}\text { - FL containing UVA/B radiation had similar } \\
\text { effectiveness as } 1,25(\mathrm{OH})_{2} \mathrm{D}_{3} \text { for minimizing } \\
\text { tibial dyschondroplasia }(\mathrm{TD}) \\
\text { - UVA/B radiation was able to compensate for } \\
\text { dietary deficiencies at some doses to reduce } \\
\text { TD and rickets }\end{array}$ \\
\hline $\begin{array}{l}\text { Mitchell et al. } \\
\text { (1997) } \\
\text { (A series of } 4 \\
\text { experiments, first } \\
\text { experiment } \\
\text { applied UV light) }\end{array}$ & $\begin{array}{l}\text { Genetically } \\
\text { selected LTD and } \\
\text { HTD Chickens } \\
\text { (experimental } \\
\text { cages) }\end{array}$ & $0-16$ & $\begin{array}{l}\text { - } \mathrm{FL}+\text { Sleeves (UV } \\
\text { blocked) } \\
\text { - } \mathrm{FL}+\text { UVA/B }(3.4 \%)\end{array}$ & - & $\begin{array}{l}\text { - UVA/B exposure significantly increased body } \\
\text { weight, bone ash, and plasma dialyzable P } \\
\text { and reduced TD in LTD but not HTD chicks }\end{array}$ \\
\hline $\begin{array}{l}\text { Edwards et al. } \\
\text { (1994) } \\
\text { (A series of } 3 \\
\text { experiments) }\end{array}$ & $\begin{array}{l}\text { Male broilers } \\
\text { (experimental } \\
\text { cages) }\end{array}$ & $0-16$ & 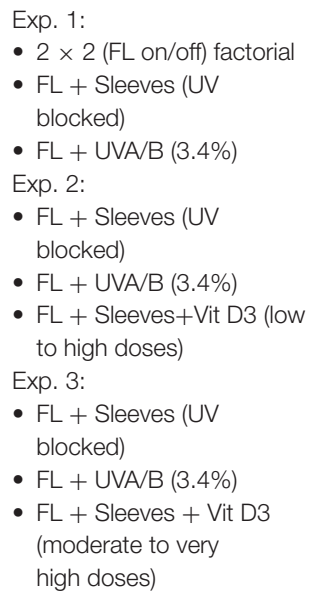 & - & $\begin{array}{l}\text { - UVA/B radiation compensated for dietary } \\
\text { deficiency in cholecalciferol. Higher levels of } \\
\text { dietary cholecalciferol had equivalent impacts } \\
\text { on bird growth and skeletal health as } \\
\text { exposure to the UVA/B radiation }\end{array}$ \\
\hline
\end{tabular}

LED, Light emitting diodes; FL, Fluorescent light; IL, Incandescent light; NL, Natural light; UVA, Ultraviolet A; UVB, Ultraviolet B; UVA/B, Ultraviolet A and B; HTD and LTD, High and Low incidence of Tibial Dyschondroplasia, respectively. ${ }^{a}$ Where the supplemental UV light was discontinuous across the light period, the hours (h) of supplementation are included within the brackets. ${ }^{b}$ Light intensity and UV irradiance intensity, and percentage (\%) of UV outputs are not presented if unspecified in the original paper.

conversion ratio (House et al., 2020a). Another study by James et al. $(2018,2020)$ supplemented both UVA and UVB to look at the different impacts of both types of UV radiation. Broilers across the rearing period were exposed to LED-white light only as a control, LED + UVA, or LED + UVA/B (James et al., 2018, 2020). Multiple measures were taken on both welfare indicators and performance across the study duration. Under UVA light, birds had better plumage (males only), shorter tonic immobility duration (lower fear), and lower mortality than control birds (James et al., 2018, 2020). Birds in both UV treatments showed improved walking ability with lower gait scores (James et al., 2018). There were no treatment impacts on breast and leg weights, but growth performance did differ (James et al., 2020). Birds reared with UVA light had slower initial growth rates; male broilers exposed to UVA/B reached their finishing weight earlier than control males, female broilers reached finishing weight earlier under both UVA and UVA/B light (James et al., 2020). Detrimental impacts of the UV supplementation were not observed. Bailie et al. (2013) investigated the provision of natural light through windows (that can pass visible light and a small amount of UV radiation) in commercial broiler houses, combined with straw bales on the floor to evaluate if the natural light and straw bales could improve bird behavior and leg health. Results showed that birds under natural light 
spent a lower percentage of time lying and resting and a greater percentage of time ground pecking than the birds reared in the absence of natural light. Preening, resting, and aggression were not affected by either the natural light or straw bales, but gait and leg health was improved under natural light indicating positive impacts without detrimental consequences (Bailie et al., 2013).

In further research aimed at specifically physical impacts, the effects of varying timing of UVA/B radiation exposure on skeletal health in birds fed a Vit- $\mathrm{D}_{3}$-deficient diet was investigated (Edwards et al., 1994; Elliot and Edwards, 1997; Edwards, 2003). The UV radiation had several positive impacts including increased body weight, bone ash and plasma $\mathrm{Ca}$ and decreased skeletal disorders of rickets and tibial dyschondroplasia (Edwards et al., 1994; Elliot and Edwards, 1997; Mitchell et al., 1997; Edwards, 2003). The radiation did not have to be applied continuously, but the first 3 days were identified to be a critical period where differences were seen in birds exposed on day 1 vs. those that had their first exposure on day 4 (Edwards, 2003). Variation in the benefits also depended on precisely how long birds were exposed for and where the lamps were placed with lamps below the bird having greater effect than those above the bird (Edwards, 2003) indicating the legs and feet to be areas of peak radiation absorbance, in accordance with the high presence of 7-DHC (Schutkowski et al., 2013). Another study by Zhang et al. (2006) also demonstrated that the addition of UV light (exact wavelengths unspecified) from the second week onwards during broiler rearing increased body weight relative to control birds exposed to incandescent light only, although not consistently across every week. UV radiation also increased shank length, bone density and serum $\mathrm{Ca}$ indicating the beneficial physiological impacts of this light source and no documented negative impacts, although sheds with different light types were not replicated (Zhang et al., 2006). Similarly, UV light (predominantly UVA, 310-390 nm) exposure from insect trap lights across rearing had no detrimental (but also no beneficial) impacts on broiler growth, mortality, feed consumption, or feed conversion relative to control birds (Hogsette and Wilson, 1999).

Overall, this small collection of studies indicate that UV light supplementation can have positive impacts on broiler health, fearfulness, stress susceptibility, and performance with no clear evidence of detrimental impacts. The provision of UVA or UVA/B wavelengths can have differing impacts, and there is indication that the precise timing and place of exposure will determine whether positive skeletal effects are seen. However, there needs to be more research on optimal timing of exposure commercially, particularly for UVB wavelengths which can cause damage with high exposure and thus may limit practical application. A cost-benefit analysis of health and welfare improvements for UV supplementation in broilers could help producers decide whether to invest in new lighting systems that include UV radiation of both UVA and/or UVB wavelengths. Further verification commercially is required with the positive evidence to date warranting additional study of UV wavelengths as a method for optimizing broiler welfare in modern broiler housing practices.

\section{EFFECTS OF UV LIGHT ON THE BEHAVIOR OF OTHER POULTRY SPECIES AND CAPTIVE BIRDS}

In addition to domestic chickens, the UV spectrum is important for other domestic fowl including turkeys, duck, and quail although the available research is more limited as illustrated in Table 5. These other poultry species can also perceive UVA light (Hart et al., 1999; Moinard et al., 2001; Barber et al., 2006) with turkeys showing greater spectral sensitivity than ducks (Barber et al., 2006). These UV wavelengths may be used in conspecific communication, food selection or have as yet undiscovered implications for how these birds perceive their environmental surroundings.

Turkey feathers will fluoresce under UVA light as well as the feet and legs of young chicks, and the featherless head region of adult males (Sherwin and Devereux, 1999; Bartels et al., 2017); it has been suggested that UVA wavelengths may play a role in the development of injurious pecking behavior (Sherwin and Devereux, 1999; Dalton et al., 2013). Sherwin and Devereux (1999) found a relationship between the age of development of UVA-reflective feather markings on specific body regions and the start of pecking toward those regions. They suggested these regions may appear "abnormal" under conventional lighting (minus UV wavelengths) thus attracting conspecifics toward those areas. Supporting this, when given a choice, turkey poults preferred UVA supplemented fluorescent light (Moinard and Sherwin, 1999). Additionally, enriched environments that included physical enrichments as well as UVA and UVB light supplementation resulting in reduced pecking injuries in comparison with non-enriched standard rooms of incandescent or fluorescent lighting (Sherwin et al., 1999). Providing enrichments including supplemental UV light may reduce pecking injuries in turkeys housed at higher light intensities (Moinard et al., 2001). A further study found no effect of UV light, higher white light intensities, and foraging enrichments on production parameters such as body weight gain and feed conversion efficiency but fewer birds had to be culled as a result of injurious pecking (Lewis et al., 2000a).

The role of specifically the UV light in these studies is uncertain but may have had an additive effect if the birds were able to better perceive their environment under the fuller spectrum lighting (Sherwin et al., 1999; Lewis et al., 2000a). Feather pecking behavior is often believed to be redirected foraging behavior, and thus UVA light is proposed to play a role in the development of appropriate foraging behavior (Moinard et al., 2001). Potential support for the role of UVA light in foraging behavior comes from tests with wild turkeys (Meleagris gallopavo) where both male and female adults avoided food containing a UV-absorbent, post-ingestive repellent but unconditioned turkeys showed no preference for UV food cues indicating the potential communicative value of UVA wavelengths (Werner et al., 2014).

There are even fewer studies that have explored how UV light affects ducks. House et al. (2020b) investigated the effect of supplemented UVA light on duck welfare and production 
TABLE 5 | Effects of UV light on behavior, growth, and production of other poultry species.

\begin{tabular}{|c|c|c|c|c|c|}
\hline References & $\begin{array}{l}\text { Species } \\
\text { (housing type) }\end{array}$ & $\begin{array}{l}\text { Age } \\
\text { (days) }\end{array}$ & Light treatments & Light intensity ${ }^{a}$ & $\begin{array}{l}\text { Growth, production, and behavioral } \\
\text { observations }\end{array}$ \\
\hline $\begin{array}{l}\text { House et al. } \\
\text { (2020b) }\end{array}$ & $\begin{array}{l}\text { Pekin duck } \\
\text { (experimental floor } \\
\text { pens) }\end{array}$ & $0-35$ & $\begin{array}{l}\text { - LED } \\
\text { - LED + UVA }\end{array}$ & $\begin{array}{l}\text { Day 1-10: } 20 \text { lux } \\
\text { Day 11-35: } 5 \text { lux }\end{array}$ & $\begin{array}{l}\text { - UVA lighting had no effect on body weight, } \\
\text { feed conversion efficiency, or gait; however, it } \\
\text { decreased stress and fear responses }\end{array}$ \\
\hline Li et al. (2014) & $\begin{array}{l}\text { Korean quail } \\
\text { (experimental } \\
\text { cages) }\end{array}$ & $3-38$ & $\begin{array}{l}\text { - UV-0 (control) } \\
\text { - UVB-1 }\left(1.4 \mu \mathrm{W} / \mathrm{cm}^{2}\right) \\
\text { - UVB-2 }\left(2.8 \mu \mathrm{W} / \mathrm{cm}^{2}\right) \\
\text { - UVB-3 }\left(5.6 \mu \mathrm{W} / \mathrm{cm}^{2}\right) \\
\text { - UVB-4 }\left(8.4 \mu \mathrm{W} / \mathrm{cm}^{2}\right)\end{array}$ & $\begin{array}{l}\text { Day 0-9: } 30 \text { lux } \\
\text { Day 10-38: } 20 \text { lux }\end{array}$ & $\begin{array}{l}\text { - The most efficient intensity of UVB exposure } \\
\text { was } 1.4 \mu \mathrm{W} / \mathrm{cm}^{2} \text { for } 1 \mathrm{~h} \text { to improve immune } \\
\text { responses and carcass characteristics }\end{array}$ \\
\hline Smith et al. (2005) & $\begin{array}{l}\text { Japanese quail } \\
\text { (experimental floor } \\
\text { pens) }\end{array}$ & $1-21$ & $\begin{array}{l}\text { - } \mathrm{FL} \\
\text { - FL + UVA }\end{array}$ & - & $\begin{array}{l}\text { - UV light had no impact during rearing of quail } \\
\text { as it did not affect stress responses as } \\
\text { indicated by behavior and plasma } \\
\text { corticosterone concentrations }\end{array}$ \\
\hline $\begin{array}{l}\text { Moinard et al. } \\
\text { (2001) } \\
\text { (2 experiments) }\end{array}$ & $\begin{array}{l}\text { Turkey } \\
\text { (experimental floor } \\
\text { pens) }\end{array}$ & $0-5 w k$ & $\begin{array}{l}\text { Exp. 1: } \\
\text { - IL + UVA (5/10 lux) } \\
\text { - FL + UVA (5/10 lux) } \\
\text { Exp. 2: } \\
\text { - FL + UVA (5 lux) } \\
\text { - FL + UVA (10 lux }) \\
\text { - FL + UVA (36 lux }) \\
\text { - FL + UVA (70 lux })\end{array}$ & $\begin{array}{l}5 \pm 0.3 / 10 \pm 0.3 \text { lux, and } 5 \\
\pm 0.3 / 10 \pm 0.3 \text { lux, } \\
\text { respectively; UVA irradiance } \\
\text { intensity } 0.16 \mathrm{~W} / \mathrm{m}^{2} \text { (under } \\
\text { the tube) } \\
5 \pm 0.3,10 \pm 0.3,36 \pm \\
1.2 \text {, and } 70 \pm 1.9 \text { lux, } \\
\text { respectively; UVA irradiance } \\
\text { intensity } 0.16 \mathrm{~W} / \mathrm{m}^{2} \text { (under } \\
\text { the tube) }\end{array}$ & $\begin{array}{l}\text { - FL of either intensity reduced tail and wing } \\
\text { injuries due to pecking behaviors compared } \\
\text { with IL } \\
\text { - The incidence of injuries was positively } \\
\text { correlated with intensity of FL } \\
\text { - Turkeys can be housed under FL up to } 10 \\
\text { lux, if enrichments including supplemental } \\
\text { UVA light are also provided }\end{array}$ \\
\hline $\begin{array}{l}\text { Lewis et al. } \\
\text { (2000a) } \\
\text { (A series of } 6 \\
\text { experiments) }\end{array}$ & $\begin{array}{l}\text { Turkey } \\
\text { (experimental floor } \\
\text { pens) }\end{array}$ & 0-20 wk & $\begin{array}{l}\text { - IL (and/or EE) + UVA } \\
\text { - FL (and/or EE) + UVA }\end{array}$ & $\begin{array}{l}\text { UVA irradiance intensity at } \\
\text { floor level between } \\
0.06-0.16 \mathrm{~W} / \mathrm{m}^{2}\end{array}$ & $\begin{array}{l}\text { - UV supplementation did not affect body } \\
\text { weight, feed intake, feed conversion efficiency, } \\
\text { and leg integrity } \\
\text { - UV supplementation did interact with white } \\
\text { light intensity and environmental enrichment } \\
\text { to reduce culling resulting from } \\
\text { injurious pecking }\end{array}$ \\
\hline $\begin{array}{l}\text { Moinard and } \\
\text { Sherwin (1999) }\end{array}$ & $\begin{array}{l}\text { Turkey } \\
\text { (floor pens and } \\
\text { choice chambers) }\end{array}$ & $0-5 w k$ & $\begin{array}{l}\text { - } F L \\
\text { - FL + UVA }\end{array}$ & $\begin{array}{l}15 \text { lux, UVA irradiance } \\
\text { intensity } 0.0117 \mathrm{~W} / \mathrm{m}^{2} \text { and } \\
\text { UVB irradiance intensity } \\
0.0001 \mathrm{~W} / \mathrm{m}^{2} \text { in UV } \\
\text { supplemented home pens. } \\
\text { Whereas, } 0.028 \mathrm{~W} / \mathrm{m}^{2} \text { UVA } \\
\text { irradiance intensity in UV } \\
\text { supplemented choice } \\
\text { chambers }\end{array}$ & $\begin{array}{l}\text { - Birds preferred a supplementary UV chamber } \\
\text { than a UV-deficient lighting environment } \\
\text { - The preference was stronger in birds raised } \\
\text { without UV supplementation suggesting } \\
\text { novelty may have contributed to preferences }\end{array}$ \\
\hline $\begin{array}{l}\text { Sherwin et al. } \\
\text { (1999) }\end{array}$ & $\begin{array}{l}\text { Turkey } \\
\text { (experimental floor } \\
\text { pens) }\end{array}$ & $0-35$ & $\begin{array}{l}\text { - } \mathrm{IL} \text { (continuous) } \\
\text { - } \mathrm{IL} \text { (intermittent) } \\
\text { - } \mathrm{IL}+\mathrm{EE}+\mathrm{UVA} \\
\text { - } \mathrm{FL}\end{array}$ & $\begin{array}{l}5 \text { lux, UVA irradiance } \\
\text { intensity } 0.16 \mathrm{~W} / \mathrm{m}^{2} \text { (under } \\
\text { the tube) }\end{array}$ & $\begin{array}{l}\text { - Turkeys reared with environmental } \\
\text { enrichment including UV supplementation } \\
\text { showed fewer pecking injuries }\end{array}$ \\
\hline
\end{tabular}

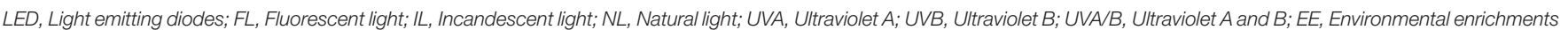
(visual barriers, straw, and pecking substrates). ${ }^{a}$ a Light intensity and UV irradiance intensity, and percentage (\%) of UV outputs are not presented if unspecified in the original paper.

parameters, where day-old ducklings were reared under LEDwhite light or LED-white and UVA light for 35 days. The ducks exposed to the UVA wavelengths showed several improvements in welfare parameters and stress measures such as lower fear responses and lower composite asymmetry although no effects on production parameters of body weight or feed conversion ratio were seen (House et al., 2020b). The morphology of the duck's eyes was also different depending on the light environment they were reared in House et al. (2020b) emphasizing the physical impacts that could affect perception of their surroundings.

The role of UVA light in foraging has been suggested to be less important for ducks that would typically feed underwater compared with species that feed on land (Barber et al., 2006), but its role in signaling for domestic ducks is uncertain. In mallards (Anas platyrhynchos), UVA reflectance of the male's bill negatively correlates with sperm performance (Peters et al., 2004) which could be used by females to determine their maternal investment of specific compounds into their eggs (Giraudeau et al., 2011). Production ducks can be housed in both closed and open-sided sheds with exposure to sunlight. The role that UV wavelengths may play in breeder as well as grower flocks is currently unclear. In contrast, exposure to UV light or not during rearing for Japanese quail had no significant impacts on the birds' behavior and stress responses (Smith et al., 2005). In Korean quail 
(Coturnix coturnix) supplementation of UVB light did improve immune index parameters, live weight and carcass quality ( $\mathrm{Li}$ et al., 2014).

The importance of UV supplementation is not limited to domestic poultry species but can play a role in the behavior, physiology, and welfare of other captive species including zoologically housed species (Ross et al., 2013; Drake et al., 2017; Tröndle et al., 2018) or laboratory model species such as the zebra finch or starling (Bennett et al., 1996; Maddocks et al., 2002). UV supplementation often has positive effects but there can be deleterious implications such as photo bleaching and compromised pro-inflammatory immune responses (Blount and Pike, 2012). Thus, overall, it is important to consider ecological backgrounds for captive and domesticated birds as well as the current housing environment or life history of the bird to determine if UV supplementation will enhance or compromise bird health and behavior.

\section{CONCLUSION}

The provision of UV light in poultry housing is still under consideration for implementation and may not be a rapid solution to improve bird welfare before further research. However, the literature has shown that UVA supplementation encourages the birds to express their natural behaviors such as foraging, ground pecking, preening, dustbathing and locomotor activity. In turkeys, UVA may reduce pecking injuries. UVA likely exerts its effect in retinal but not in hypothalamic photoreceptors improving behaviors and welfare in most of the domestic poultry species and captive birds. UVB has an impact on the development of skeletal health, and it could maintain persistency in terminal egg production and prevent osteoporosis. Moreover, an optimum duration of additional UVB exposure with an adequate vitamin $\mathrm{D}_{3}$ enriched diet could improve poultry growth and production. Nevertheless,

\section{REFERENCES}

Ameenuddin, S., Sunde, M., and Cook, M. (1985). Essentiality of vitamin $\mathrm{D}_{3}$ and its metabolites in poultry nutrition: A review. Worlds Poult. Sci. J. 41, 52-63. doi: 10.1079/WPS19850005

Angel, R. (2007). Metabolic disorders: limitations to growth of and mineral deposition into the broiler skeleton after hatch and potential implications for leg problems. J. Appl. Poult. Res. 16, 138-149. doi: 10.1093/japr/16.1.138

Atencio, A., Edwards, H. Jr., and Pesti, G. (2005). Effects of vitamin $\mathrm{D}_{3}$ dietary supplementation of broiler breeder hens on the performance and bone abnormalities of the progeny. Poult. Sci. 84, 1058-1068. doi: $10.1093 / \mathrm{ps} / 84.7 .1058$

Averós, X., and Estevez, I. (2018). Meta-analysis of the effects of intensive rearing environments on the performance and welfare of broiler chickens. Poult. Sci. 97, 3767-3785. doi: $10.3382 /$ ps/pey243

Bailie, C., Ball, M., and O'Connell, N. (2013). Influence of the provision of natural light and straw bales on activity levels and leg health in commercial broiler chickens. Animal 7, 618-626. doi: 10.1017/S1751731112002108

Barber, C., Prescott, N., Jarvis, J., Sueur, C. L., Perry, G., and Wathes, C. (2006). Comparative study of the photopic spectral sensitivity of domestic ducks (Anas the potential detrimental effects of UV lights, such as increased feather pecking in laying hens, warrants further study before commercial implementation.

\section{RECOMMENDATIONS FOR FUTURE RESEARCH}

The following research questions have been identified:

- What is the optimum level of intensity of UVA light that could be applied to maximize behavioral and welfare improvement without increasing feather pecking?

- What is the optimal timing and duration of UV (A and B) exposure to ensure benefits?

- How would UV supplementation be applied to best match changing requirements across bird strain and age?

- How does the full spectral light (combination of UVA and UVB) affect the birds compared to individual UV light (A or B) supplementation?

- Are there interaction effects between UV light supplementation and specific types of housing systems?

\section{AUTHOR CONTRIBUTIONS}

MR: conceptualization and original draft preparation. DC: conceptualization, writing, review, and editing. Both authors contributed to the article and approved the final version.

\section{FUNDING}

MR was supported by postgraduate scholarships through the University of New England (UNE) and the Commonwealth Scientific and Industrial Research Organization (CSIRO). Open access publication fees were supported by a Commonwealth Scientific and Industrial Research Organisation (CSIRO) McIlrath Trust Scholarship to MR. platyrhynchos domesticus), turkeys (Meleagris gallopavo gallopavo) and humans. Br. Poult. Sci. 47, 365-374. doi: 10.1080/00071660600753870

Barnkob, L. L., Argyraki, A., and Jakobsen, J. (2020). Naturally enhanced eggs as a source of vitamin D: a review. Trends Food. Sci. Technol. 102, 62-70. doi: 10.1016/j.tifs.2020.05.018

Bartels, T., Lütgeharm, J., Wähner, M., and Berk, J. (2017). UV reflection properties of plumage and skin of domesticated turkeys (Meleagris gallopavo $f$. dom.) as revealed by UV photography. Poult. Sci. 96, 4134-4139. doi: 10.3382/ps/pex256

Baxter, M., Joseph, N., Osborne, V., and Bedecarrats, G. (2014). Red light is necessary to activate the reproductive axis in chickens independently of the retina of the eye. Poult. Sci. 93, 1289-1297. doi: 10.3382/ps.2013-03799

Bédécarrats, G. Y. (2015). Control of the reproductive axis: balancing act between stimulatory and inhibitory input. Poult. Sci. 94, 810-815. doi: $10.3382 / \mathrm{ps} / \mathrm{peu} 042$

Bennett, A. T., Cuthill, I. C., Partridge, J. C., and Maier, E. J. (1996). Ultraviolet vision and mate choice in zebra finches. Nature 380, 433-435. doi: $10.1038 / 380433 \mathrm{a} 0$

Benson, E., Hougentogler, D., McGurk, J., Herrman, E., and Alphin, R. (2013). Durability of incandescent, compact fluorescent, and light emitting diode lamps in poultry conditions. Appl. Eng. Agric. 29, 103-111. doi: 10.13031/2013.42531 
Bessei, W. (2006). Welfare of broilers: a review. Worlds Poult. Sci. J. 62, 455-466. doi: $10.1017 /$ S0043933906001085

Blount, J. D., and Pike, T. W. (2012). Deleterious effects of light exposure on immunity and sexual coloration in birds. Funct. Ecol. 26, 37-45. doi: $10.1111 / j .1365-2435.2011 .01926 . x$

Bowmaker, J. K., Heath, L. A., Wilkie, S. E., and Hunt, D. M. (1997). Visual pigments and oil droplets from six classes of photoreceptor in the retinas of birds. Vision Res. 37, 2183-2194. doi: 10.1016/s0042-6989(97)00026-6

Bracke, M. B., Koene, P., Estevez, I., Butterworth, A., and de Jong, I. C. (2019). Broiler welfare trade-off: a semi-quantitative welfare assessment for optimised welfare improvement based on an expert survey. PLOS ONE 14:e0222955. doi: 10.1371/journal.pone.0222955

Buyse, J., Simons, P., Boshouwers, F., and Decuypere, E. (1996). Effect of intermittent lighting, light intensity and source on the performance and welfare of broilers. Worlds Poult. Sci. J. 52, 121-130. doi: 10.1079/WPS19960012

Campbell, D. L. M. (2020). Skeletal health of layers across all housing systems and future research directions for Australia. Anim. Prod. Sci. 61, 883-892. doi: 10.1071/AN19578

Casey-Trott, T. M., Korver, D. R., Guerin, M. T., Sandilands, V., Torrey, S., and Widowski, T. M. (2017). Opportunities for exercise during pullet rearing, Part II: Long-term effects on bone characteristics of adult laying hens at the end-of-lay. Poult. Sci. 96, 2518-2527. doi: 10.3382/ps/pex060

CIWF (2019). Statistics: Broiler Chickens-Farm Animal Welfare Compendium 2019. Retrived from: https://www.ciwf.org.uk/media/5235303/StatisticsBroiler-chickens.pdf (accessed August 27, 2019)

Cuthill, I. C., Partridge, J. C., Bennett, A. T., Church, S. C., Hart, N. S., and Hunt, S. (2000). Ultraviolet vision in birds. Adv. Stud. Behav. 29, 159-214. doi: $10.1016 /$ S0065-3454(08)60105-9

Dalton, H., Wood, B., and Torrey, S. (2013). Injurious pecking in domestic turkeys: development, causes, and potential solutions. Worlds Poult. Sci. J. 69, 865-876. doi: $10.1017 /$ S004393391300086X

Davies, W. I., Turton, M., Peirson, S. N., Follett, B. K., Halford, S., GarciaFernandez, J. M., et al. (2012). Vertebrate ancient opsin photopigment spectra and the avian photoperiodic response. Biol. Lett. 8, 291-294. doi: 10.1098/rsbl.2011.0864

Dawkins, M. S., Donnelly, C. A., and Jones, T. A. (2004). Chicken welfare is influenced more by housing conditions than by stocking density. Nature 427 , 342-344. doi: 10.1038/nature02226

de Jonge, J., and van Trijp, H. C. (2013). The impact of broiler production system practices on consumer perceptions of animal welfare. Poult. Sci. 92, 3080-3095. doi: 10.3382/ps.2013-03334

de Matos, R. (2008). Calcium metabolism in birds. Vet. Clin. North. Am. Exot. Anim. Pract. 11, 59-82. doi: 10.1016/j.cvex.2007.09.005

DeLuca, H. F. (2004). Overview of general physiologic features and functions of vitamin D. Am. J. Clin. Nutr. 80, 1689S-1696S. doi: 10.1093/ajcn/80.6.1689S

Drake, G. J.-C., Shea, R. L., Fidgett, A., Lopez, J., and Christley, R. M. (2017). Provision of ultraviolet basking lights to indoor housed tropical birds and their effect on suspected vitamin $\mathrm{D}_{3}$ deficiency. J. Zoo. Aquar. Res. 5, 151-157. doi: $10.19227 /$ jzar.v5i4.283

Edwards, H. M. Jr. (2003). Effects of u.v. irradiation of very young chickens on growth and bone development. Br. J. Nutr. 90, 151-160. doi: 10.1079/bjn2003860

Edwards, Jr. H. M., Elliot, M. A., Sooncharernying, S., and Britton, W. M. (1994). Quantitative requirement for cholecalciferol in the absence of ultraviolet light. Poult. Sci. 73, 288-294. doi: 10.3382/ps.0730288

Elliot, M. A., and Edwards, H. M. Jr. (1997). Effect of 1,25dihydroxycholecalciferol, cholecalciferol, and fluorescent lights on the development of tibial dyschondroplasia and rickets in broiler chickens. Poult. Sci. 76, 570-580. doi: 10.1093/ps/76.4.570

Engelsen, O. (2010). The relationship between ultraviolet radiation exposure and vitamin D status. Nutrients 2, 482-495. doi: 10.3390/nu20 50482

England, A., and Ruhnke, I. (2020). The influence of light of different wavelengths on laying hen production and egg quality. Worlds Poult. Sci. J. 76, 443-458. doi: $10.1080 / 00439339.2020 .1789023$

Foster, R., and Follett, B. (1985). The involvement of a rhodopsin-like photopigment in the photoperiodic response of the Japanese quail. J. Comp. Physiol. 157, 519-528.
García-Fernández, J. M., Cernuda-Cernuda, R., Davies, W. I., Rodgers, J., Turton, M., Peirson, S. N., et al. (2015). The hypothalamic photoreceptors regulating seasonal reproduction in birds: a prime role for VA opsin. Front. Neuroendocrinol. 37, 13-28. doi: 10.1016/j.yfrne.2014.11.001

Giraudeau, M., Duval, C., Czirják, G., Bretagnolle, V., Eraud, C., McGraw, K., et al. (2011). Maternal investment of female mallards is influenced by male carotenoid-based coloration. Proc. Royal Soc. B 278, 781-788. doi: 10.1098/rspb.2010.1115

Gongruttananun, N. (2011). Influence of red light on reproductive performance, eggshell ultrastructure, and eye morphology in Thai-native hens. Poult. Sci. 90, 2855-2863. doi: 10.3382/ps.2011-01652

Govardovskii, V., and Zueva, L. (1977). Visual pigments of chicken and pigeon. Vision Res. 17, 537-543. doi: 10.1016/0042-6989(77)90052-9

Hanlon, C., Ramachandran, R., Zuidhof, M. J., and Bédécarrats, G. Y. (2020). Should I lay or should I grow: photoperiodic versus metabolic cues in chickens. Front. Physiol. 11:707. doi: 10.3389/fphys.2020.00707

Harlander-Matauschek, A., Rodenburg, T. B., Sandilands, V., Tobalske, B. W., and Toscano, M. J. (2015). Causes of keel bone damage and their solutions in laying hens. Worlds Poult. Sci. J. 71, 461-472. doi: 10.1017/S0043933915002135

Hart, N. S., Partridge, J. C., and Cuthill, I. (1999). Visual pigments, cone oil droplets, ocular media and predicted spectral sensitivity in the domestic turkey (Meleagris gallopavo). Vision Res. 39, 3321-3328. doi: 10.1016/S0042-6989(99)00071-1

Hogsette, J. A., and Wilson, H. R. (1999). Effects on commercial broiler chicks of constant exposure to ultraviolet light from insect traps. Poult. Sci. 78, 324-326. doi: $10.1093 / \mathrm{ps} / 78.3 .324$

Hogsette, J. A., Wilson, H. R., and Semple-Rowland, S. L. (1997). Effects on white Leghorn hens of constant exposure to ultraviolet light from insect traps. Poult. Sci. 76, 1134-1137. doi: 10.1093/ps/76.8.1134

House, G. M., Sobotik, E., Nelson, J., and Archer, G. (2020a). Effect of the addition of ultraviolet light on broiler growth, fear, and stress response. J. Appl. Poult. Res. 29, 402-408. doi: 10.1016/j.japr.2020.01.003

House, G. M., Sobotik, E. B., Nelson, J. R., and Archer, G. S. (2020b). Effects of ultraviolet light supplementation on pekin duck production, behavior, and welfare. Animals 10:833. doi: 10.3390/ani10050833

Hunt, D. M., Carvalho, L. S., Cowing, J. A., and Davies, W. L. (2009). Evolution and spectral tuning of visual pigments in birds and mammals. Philos. Trans. $R$. Soc. 364, 2941-2955. doi: 10.1098/rstb.2009.0044

James, C., Asher, L., Herborn, K., and Wiseman, J. (2018). The effect of supplementary ultraviolet wavelengths on broiler chicken welfare indicators. Appl. Anim. Behav. Sci. 209, 55-64. doi: 10.1016/j.applanim.2018. 10.002

James, C., Wiseman, J., and Asher, L. (2020). The effect of supplementary ultraviolet wavelengths on the performance of broiler chickens. Poult. Sci. 99, 5517-5525. doi: 10.1016/j.psj.2020.07.018

Jones, E. K., Prescott, N. B., Cook, P., White, R. P., and Wathes, C. M. (2001). Ultraviolet light and mating behaviour in domestic broiler breeders. Br. Poult. Sci. 42, 23-32. doi: 10.1080/713655008

Käppeli, S., Gebhardt-Henrich, S. G., Fröhlich, E., Pfulg, A., Schäublin, H., and Stoffel, M. H. (2011). Effects of housing, perches, genetics, and 25hydroxycholecalciferol on keel bone deformities in laying hens. Poult. Sci. 90, 1637-1644. doi: 10.3382/ps.2011-01379

Kristensen, H. H., Perry, G., Prescott, N., Ladewig, J., Ersbøll, A. K., and Wathes, C. (2006). Leg health and performance of broiler chickens reared in different light environments. Br. Poult. Sci. 47, 257-263. doi: 10.1080/00071660600753557

Kristensen, H. H., Prescott, N. B., Perry, G. C., Ladewig, J., Ersbøll, A. K., Overvad, K. C., et al. (2007). The behaviour of broiler chickens in different light sources and illuminances. Appl. Anim. Behav. Sci. 103, 75-89. doi: 10.1016/j.applanim.2006.04.017

Kühn, J., Schutkowski, A., Hirche, F., Baur, A. C., Mielenz, N., and Stangl, G. I. (2015). Non-linear increase of vitamin D content in eggs from chicks treated with increasing exposure times of ultraviolet light. J. Steroid Biochem. Mol. Biol. 148, 7-13. doi: 10.1016/j.jsbmb.2014.10.015

Kühn, J., Schutkowski, A., Kluge, H., Hirche, F., and Stangl, G. I. (2014). Free-range farming: a natural alternative to produce vitamin D-enriched eggs. Nutrition 30, 481-484. doi: 10.1016/j.nut.2013.10.002

Kühn, J., Wassermann, C., Ebschke, S., Schutkowski, A., Thamm, K., WenschDorendorf, M., et al. (2019). Feasibility of artificial light regimes to increase 
the vitamin D content in indoor-laid eggs. Poult. Sci. 98, 5177-5187. doi: $10.3382 / \mathrm{ps} /$ pez234

Lewis, P., and Morris, T. (1998). Responses of domestic poultry to various light sources. Worlds Poult. Sci. J. 54, 7-25. doi: 10.1079/WPS19980002

Lewis, P., and Morris, T. (2000). Poultry and coloured light. Worlds Poult. Sci. J. 56, 189-207. doi: 10.1079/WPS20000015

Lewis, P. D., Ghebremariam, W., and Gous, R. M. (2007). Illuminance and UV-A exposure during rearing affects egg production in broiler breeders transferred to open-sided adult housing. Br. Poult. Sci. 48, 424-429. doi: 10.1080/00071660701543105

Lewis, P. D., and Gous, R. M. (2009). Responses of poultry to ultraviolet radiation. Worlds Poult. Sci. J. 65, 499-510. doi: 10.1017/s0043933909000361

Lewis, P. D., Perry, G., Sherwin, C., and Moinard, C. (2000a). Effect of ultraviolet radiation on the performance of intact male turkeys. Poult. Sci. 79, 850-855. doi: $10.1093 / \mathrm{ps} / 79.6 .850$

Lewis, P. D., Perry, G. C., and Morris, T. R. (2000b). Ultraviolet radiation and laying pullets. Br. Poult. Sci. 41, 131-135. doi: 10.1080/713654916

Li, M., Gao, Y., Lan, G., and Gu, Z. (2014). Effects of ultraviolet-B radiation on immunity and carcass characteristics in quail. J. Appl. Poult. Res. 23, 429-436. doi: 10.3382/japr.2013-00919

Lietzow, J., Kluge, H., Brandsch, C., Seeburg, N., Hirche, F., Glomb, M., et al. (2012). Effect of short-term UVB exposure on vitamin D concentration of eggs and vitamin D status of laying hens. J. Agric. Food Chem. 60, 799-804. doi: $10.1021 /$ jf204273n

Liu, K., Wang, K., Fei, T., Chai, L., and Xin, H. (2018). "Computer visionbased animal preference assessment - do laying hen chicks prefer light with UVA radiation?", in ASABE Annual International Meeting (Detroit). doi: 10.13031/aim.201800193

Maddocks, S. A., Cuthill, I. C., Goldsmith, A. R., and Sherwin, C. M. (2001). Behavioural and physiological effects of absence of ultraviolet wavelengths for domestic chicks. Anim. Behav. 62, 1013-1019. doi: 10.1006/anbe.2001.1842

Maddocks, S. A., Goldsmith, A. R., and Cuthill, I. C. (2002). Behavioural and physiological effects of absence of ultraviolet wavelengths on European starlings (Sturnus vulgaris). J. Avian Biol. 33, 103-106. doi: 10.1034/j.1600-048X.2002.330117.x

Manser, C. (1996). Effects of lighting on the welfare of domestic poultry: a review. Anim. Welf. 5, 341-360.

McKenzie, R. L., Björn, L. O., Bais, A., and Ilyasd, M. (2003). Changes in biologically active ultraviolet radiation reaching the earth's surface. Photochem. Photobiol. Sci. 2, 5-15. doi: 10.1039/b211155c

Mitchell, R., Edwards Jr, H., and McDaniel, G. (1997). The effects of ultraviolet light and cholecalciferol and its metabolites on the development of leg abnormalities in chickens genetically selected for a high and low incidence of tibial dyschondroplasia. Poult. Sci. 76, 346-354. doi: 10.1093/ps/76.2.346

Moinard, C., Lewis, P., Perry, G., and Sherwin, C. (2001). The effects of light intensity and light source on injuries due to pecking of male domestic turkeys (Meleagris gallopavo). Anim. Welf. 10, 131-139.

Moinard, C., and Sherwin, C. (1999). Turkeys prefer fluorescent light with supplementary ultraviolet radiation. Appl. Anim. Behav. Sci. 64, 261-267. doi: 10.1016/S0168-1591(99)00043-X

Olanrewaju, H., Thaxton, J., Dozier, W., Purswell, J., Roush, W., and Branton, S. (2006). A review of lighting programs for broiler production. Int. J. Poult. Sci. 5, 301-308. doi: 10.3923/ijps.2006.301.308

Parvin, R., Mushtaq, M. M. H., Kim, M. J., and Choi, H. C. (2014). Light Emitting Diode (LED) as a source of monochromatic light: a novel lighting approach for immunity and meat quality of poultry. World Poult. Sci. J. 70, 557-562. doi: 10.1017/s0043933914000609

Peters, A., Denk, A., Delhey, K., and Kempenaers, B. (2004). Carotenoid-based bill colour as an indicator of immunocompetence and sperm performance in male mallards. J. Evol. Biol. 17, 1111-1120. doi: 10.1111/j.1420-9101.2004.00743.x

Petrik, M. T., Guerin, M. T., and Widowski, T. M. (2015). On-farm comparison of keel fracture prevalence and other welfare indicators in conventional cage and floor-housed laying hens in Ontario, Canada. Poult. Sci. 94, 579-585. doi: $10.3382 /$ ps/pev039

Pettersson, I. C., Weeks, C. A., Wilson, L. R. M., and Nicol, C. J. (2016). Consumer perceptions of free-range laying hen welfare. Br. Food J. 118, 1999-2013. doi: 10.1108/BFJ-02-2016-0065
Prescott, N., and Wathes, C. (1999). Spectral sensitivity of the domestic fowl (Gallus g. domesticus). Br. Poult. Sci. 40, 332-339. doi: $10.1080 / 00071669987412$

Prescott, N., Wathes, C. M., and Jarvis, J. (2003). Light, vision and the welfare of poultry. Anim. Welf. 12, 269-288.

Rajchard, J. (2009). Ultraviolet (UV) light perception by birds: a review. J. Vet. Sci. 54, 351-359. doi: 10.17221/110/2009-VETMED

Rana, M. S., Cohen-Barnhouse, A. M., Lee, C., and Campbell, D. L. M. (2021). Preference testing for ultraviolet light spectrum and intensity in laying hens. Poult. Sci. 100:101063. doi: 10.1016/j.psj.2021.101063

Reddy, I. J., David, C. G., Selvaraju, S., Mondal, S., and Kiran, G. R. (2012). GnRH1 mRNA, LH surges, steroid hormones, egg production, and intersequence pause days alter in birds exposed to longer wavelength of light in the later stages of production in Gallus gallus domesticus. Trop. Anim. Health Prod. 44, 1311-1317. doi: 10.1007/s11250-012-0073-9

Regmi, P., Deland, T. S., Steibel, J. P., Robison, S. C., Haut, R. C., Orth, M. W., et al. (2015). Effect of rearing environment on bone growth of pullets. Poult. Sci. 94, 502-511. doi: 10.3382/ps/peu041

Rios, H. V., Waquil, P. D., de Carvalho, P. S., and Norton, T. (2020). How are information technologies addressing broiler welfare? A systematic review based on the Welfare Quality ${ }^{\circledR}$ assessment. Sustainability 12:1413. doi: $10.3390 /$ su12041413

Robins, A., and Phillips, C. (2011). International approaches to the welfare of meat chickens. Worlds Poult. Sci. J. 67, 351-369. doi: 10.1017/S0043933911000341

Rosiak, J., and Zawilska, J. B. (2005). Near-ultraviolet light perceived by the retina generates the signal suppressing melatonin synthesis in the chick pineal glandan involvement of NMDA glutamate receptors. Neurosci. Lett. 379, 214-217. doi: 10.1016/j.neulet.2004.12.075

Ross, M. R., Gillespie, K. L., Hopper, L. M., Bloomsmith, M. A., and Maple, T. L. (2013). Differential preference for ultraviolet light among captive birds from three ecological habitats. Appl. Anim. Behav. Sci. 147, 278-285. doi: 10.1016/j.applanim.2013.05.006

Rozenboim, I., Robinzon, B., and Rosenstrauch, A. (1999). Effect of light source and regimen on growing broilers. Br. Poult. Sci. 40, 452-457. doi: 10.1080/00071669987197

Rufener, C., and Makagon, M. M. (2020). Keel bone fractures in laying hens: a systematic review of prevalence across age, housing systems, and strains. J. Anim. Sci. 98, S36-S51. doi: 10.1093/jas/skaa145

Ruis, M., Reuvekamp, B., Gunnink, H., and Binnendijk, G. (2010). “The effect of optimized lighting conditions on feather pecking and production of laying hens." Wageningen UR Livest. Res. Retrived from: https://library.wur.nl/ WebQuery/wurpubs/fulltext/137033 (accessed August 20, 2021).

Schröder, M. J., and McEachern, M. G. (2004). Consumer value conflicts surrounding ethical food purchase decisions: a focus on animal welfare. Int. J. Consum. Stud. 28, 168-177. doi: 10.1111/j.1470-6431.2003. 00357.x

Schutkowski, A., Krämer, J., Kluge, H., Hirche, F., Krombholz, A., Theumer, T., et al. (2013). UVB exposure of farm animals: study on a food-based strategy to bridge the gap between current vitamin $\mathrm{D}$ intakes and dietary targets. PLoS ONE 8:e69418. doi: 10.1371/journal.pone.0069418

Scrinis, G., Parker, C., and Carey, R. (2017). The caged chicken or the freerange egg? The regulatory and market dynamics of layer-hen welfare in the UK, Australia and the USA. J. Agric. Environ. Ethics 30, 783-808. doi: $10.1007 /$ s10806-017-9699-y

Sherwin, C., and Devereux, C. (1999). Preliminary investigations of ultravioletinduced markings on domestic turkey chicks and a possible role in injurious pecking. Br. Poult. Sci. 40, 429-433. doi: 10.1080/00071669987151

Sherwin, C. M., Lewis, P. D., and Perry, G. C. (1999). Effects of environmental enrichment, fluorescent and intermittent lighting on injurious pecking amongst male turkey poults. Br. Poult. Sci. 40, 592-598. doi: 10.1080/00071669986954

Smith, E., Greenwood, V., Goldsmith, A., and Cuthill, I. (2005). Effect of supplementary ultraviolet lighting on the behaviour and corticosterone levels of Japanese quail chicks. Anim. Welf. 14, 103-109

Sobotik, E. B., Nelson, J. R., and Archer, G. S. (2020). How does ultraviolet light affect layer production, fear and stress. Appl. Anim. Behav. Sci. 223:104926. doi: 10.1016/j.applanim.2019.104926 
Soliman, F. N., and El-Sabrout, K. (2020). Light wavelengths/colors: future prospects for broiler behavior and production. J. Vet. Behav. 36, 34-39. doi: 10.1016/j.jveb.2019.10.014

Spindler, B., Weseloh, T., Eßer, C., Freytag, S. K., Klambeck, L., Kemper, N., et al. (2020). The effects of UV-A light provided in addition to standard lighting on plumage condition in laying hens. Animals 10:1106. doi: 10.3390/ani10061106

Stanford, M. (2006). Effects of UVB radiation on calcium metabolism in psittacine birds. Vet. Rec. 159, 236-241. doi: 10.1136/vr.159.8.236

Tian, X. Q., Chen, T., Lu, Z., Shao, Q., and Holick, M. F. (1994). Characterization of the translocation process of vitamin $\mathrm{D}_{3}$ from the skin into the circulation. Endocrinology 135, 655-661. doi: 10.1210/en.135.2.655

Tröndle, U., Steinmetz, H. W., Rüegg, S. R., Müller, A., and Liesegang, A. (2018). UV-light and dietary vitamin D and their effects on ionized calcium and 25$\mathrm{OH}-\mathrm{D}$ plasma concentrations in captive gentoo penguins (Pygoscelis papua). J Anim. Physiol. Anim. Nutr. 102, 1419-1428. doi: 10.1111/jpn.12941

Tsutsui, K., Bentley, G. E., Bedecarrats, G., Osugi, T., Ubuka, T., and Kriegsfeld, L. J. (2010). Gonadotropin-inhibitory hormone $(\mathrm{GnIH})$ and its control of central and peripheral reproductive function. Front. Neuroendocrinol. 31, 284-295. doi: 10.1016/j.yfrne.2010.03.001

Tsutsui, K., Saigoh, E., Ukena, K., Teranishi, H., Fujisawa, Y., Kikuchi, M., et al. (2000). A novel avian hypothalamic peptide inhibiting gonadotropin release. Biochem. Biophys. Res. Commun. 275, 661-667. doi: 10.1006/bbrc.200 0.3350

Vanhonacker, F., and Verbeke, W. (2014). Public and consumer policies for higher welfare food products: challenges and opportunities. J. Agric. Environ. Ethics 27, 153-171. doi: 10.1007/s10806-013-9479-2

Vergneau-Grosset, C., and Péron, F. (2020). Effect of ultraviolet radiation on vertebrate animals: update from ethological and medical perspectives. Photochem. Photobiol. Sci. 19, 752-762. doi: 10.1039/c9pp00488b

Webster, A. (2004). Welfare implications of avian osteoporosis. Poult. Sci. 83, 184-192. doi: $10.1093 / \mathrm{ps} / 83.2 .184$

Wei, Y., Zheng, W., Li, B., Tong, Q., Shi, H., and Li, X. (2020). Effects of B-wave ultraviolet supplementation using light-emitting diodes on caged laying hens during the later phase of the laying cycle. Animals 10:15. doi: 10.3390/ani10010015

Wen, J., Livingston, K. A., and Persia, M. E. (2019). Effect of high concentrations of dietary vitamin $\mathrm{D}_{3}$ on pullet and laying hen performance, skeleton health, eggshell quality, and yolk vitamin $\mathrm{D}_{3}$ content when fed to W36 laying hens from day of hatch until 68 wk of age. Poult. Sci. 98, 6713-6720. doi: $10.3382 /$ ps/pez386
Werner, S. J., Buchholz, R., Tupper, S. K., Pettit, S. E., and Ellis, J. W. (2014). Functional significance of ultraviolet feeding cues in wild turkeys. Physiol. Behav. 123, 162-167. doi: 10.1016/j.physbeh.2013. 10.010

Whitehead, C. C., and Fleming, R. H. (2000). Osteoporosis in cage layers. Poult. Sci. 79, 1033-1041. doi: 10.1093/ps/79.7.1033

Wichman, A., Groot, R. D., Håstad, O., Wall, H., and Ruben, D. (2021). Influence of different light spectrums on behaviour and welfare in laying hens. Animals 11:924. doi: 10.3390/ani11040924

Wilkins, L. J., McKinstry, J. L., Avery, N. C., Knowles, T. G., Brown, S. N., Tarlton, J., et al. (2011). Influence of housing system and design on bone strength and keel bone fractures in laying hens. Vet. Rec. 69, 414-414. doi: 10.1136/vr.d4831

Wineland, M. J. (2002). "Fundamentals of managing light for poultry," in Commercial Chicken Meat and Egg Production, eds, D. D. Bell and W. D. Weaver (Boston, MA: Springer), 129-148.

Yamashita, T., Ohuchi, H., Tomonari, S., Ikeda, K., Sakai, K., and Shichida, Y. (2010). Opn5 is a UV-sensitive bistable pigment that couples with Gi subtype of G protein. Proc. Natl. Acad. Sci. U.S.A. 107, 22084-22089. doi: 10.1073/pnas.1012498107

Zhang, L.-X., Shi, Z.-X., Wang, X.-Y., Geng, A.-L., and Li, B.-M. (2006). Effects of ultraviolet radiation on skeleton development of broiler chickens. Agric. Sci. China 5, 313-317. doi: 10.1016/S1671-2927(06)60055-2

Conflict of Interest: The authors declare that the research was conducted in the absence of any commercial or financial relationships that could be construed as a potential conflict of interest.

Publisher's Note: All claims expressed in this article are solely those of the authors and do not necessarily represent those of their affiliated organizations, or those of the publisher, the editors and the reviewers. Any product that may be evaluated in this article, or claim that may be made by its manufacturer, is not guaranteed or endorsed by the publisher.

Copyright (C) 2021 Rana and Campbell. This is an open-access article distributed under the terms of the Creative Commons Attribution License (CC BY). The use, distribution or reproduction in other forums is permitted, provided the original author(s) and the copyright owner(s) are credited and that the original publication in this journal is cited, in accordance with accepted academic practice. No use, distribution or reproduction is permitted which does not comply with these terms. 